\title{
Bilim Diplomasisi ve Bilim Halkla İlişkileri Bağlamında "American Association for the Advancement of Science" (AAAS) ve "Royal Society" Örnekleri Üzerinden Türkiye İçin Bir Model Önerisi
}

\author{
Gonca Yıldırım \\ Dr. Öğr. Üyesi \\ goncayildirim@aydin.edu.tr \\ İstanbul Aydın Üniversitesi Illetişim Fakültesi \\ ORCID: 0000-0002-7433-0841 \\ Deniz Akbulut \\ Dr. Öğr. Üyesi \\ denizakbulut@aydin.edu.tr \\ İstanbul Aydın Üniversitesi Illetişim Fakültesi \\ ORCID: 0000-0003-0236-525X
}

\begin{abstract}
"American Association for the Advancement of Science" and "The Royal Society" in the Context of the Science Public Relations and Science Diplomacy Relation: A New Model for Turkey

Advances in information and communication technologies have made science a part of politics and international relations. While international agreements become crucial for the rapid development and spread of science, science has a critical role in solving international problems. The concept of "science diplomacy" that we have encountered in this process, is the establishment of scientific collaborations to make and carry out co-decisions for the solution of international problems. However, "science-public relations" come into play in the execution, spread, and appropriation of these partnerships and studies to all societies. While science diplomacy and science public relations have been deal with together in international academic literature there is little research in this field in Turkey. In the framework of tripartite taxonomy of science diploma$c y$, this study aims to examine the activities of the world's leading institutions: American Association for the Advancement of Science
\end{abstract}


(USA) and The Royal Society (United Kingdom); and deriving from this examination, to offer a model proposal for Turkey. This research proposes to establish the "Turkey Science Diplomacy Institute" based on the developed model following activities and cooperation.

keywords: Public relations, science public relations, science diplomacy, public diplomacy, public engagement

\section{Résumé}

\section{"Association Américaine pour liavancement de la Science " et "la Royal Society " dans le contexte de la relation entre les relations publiques scientifiques et la diplomatie scientifique: un nouveau modèle pour la Turquie}

Les progrès dans les technologies de l'information et de la communication ont fait de la science une partie intégrante de la politique et des relations internationales. Alors que les accords internationaux deviennent importants pour l'avancement et la diffusion rapides de la science ; La science joue un rôle clé dans la résolution des problèmes internationaux. Le concept de " diplomatie scientifique " que nous rencontrons dans ce processus est l'établissement de collaborations scientifiques afin de prendre et de mettre en œuvre des décisions communes pour la solution des problèmes internationaux. Cependant, les "relations publiques de Science " interviennent dans l'exécution, la diffusion et l'appropriation de ces partenariats et études à toutes les sociétés. Malgre la diplomatie scientifique et les relations publiques de Science sont souvent prises ensemble dans le monde, en Turquie etre étudiée dans un domaine moins fréquemment, rend cet article unique. Dans le cadre de la taxonomie tripartite de la diplomatie scientifique, le but de cette étude est d'examiner les activités des principales institutions mondiales: d'AAAS (American Association for the Advancement of Science) et de la Royal Société (The Royal Society) ; et découlant de ce contexte d'offre un modèle pour la Turquie. Dans le cadre des coopérations et activités développés conformément à ce modèle, cette recherche propose d'établir de " I'Institut turc de diplomatie scientifique ".

mots-clés: Relations publiques, relations publiques scientifiques, diplomatie scientifique, diplomatie publique, participation sociale 


\section{Öz}

Bilgi ve iletişim teknolojilerindeki gelişmeler bilimi, politikanın ve uluslararası ilişkilerin bir parçası haline getirmiştir. Bilimin hızla ilerlemesi ve yayılımı için uluslararası anlaşmalar önemli hale gelirken; uluslararası sorunların çözümünde de bilim, anahtar rol oynamaktadır. Bu süreçte karşımıza çıkan "bilim diplomasisi" kavramı da uluslararası sorunların çözümü için ortak kararların alınması ve yürütülmesi adına bilimsel iş birliklerinin kurulmasıdır. Ancak bu ortaklıkların ve çalışmaların yürütülmesi, yayılımı ve tüm toplumlara mal edilmesinde ise "bilim halkla ilişkileri" devreye girmektedir. Uluslararası yazında bilim diplomasisi ve bilim halkla ilişkileri sıklıkla birlikte ele alınırken Türkiye'de henüz az çalışılan bir alan olması bu makaleyi özgün kılmaktadır. Bu çalışmanın amacı, bilim diplomasisinin üçlü taksonomisi çerçevesinde, bu konuda dünyanın önde gelen kurumlarından AAAS (American Association for the Advancement of Science -Amerika Birleşik Devletleri) ve The Royal Society'nin (Birleşik Krallık) faaliyetlerinin incelenmesi ve buradan yola çıkarak Türkiye için bir model önerisi sunmaktadır. Geliştirilen bu modele uygun olarak faaliyet ve iş birlikleri kapsamında Türkiye Bilim Diplomasisi Kurumu kurulması önerilmiştir.

anahtar kelimeler: Halkla ilişkiler, bilim halkla ilişkileri, bilim diplomasisi, kamu diplomasisi, toplumsal katılım 


\section{Giriş}

Bugün karşılaşılan ekonomik, toplumsal, çevresel sorunların birçoğu küresel nedenlere dayanmakta ve küresel çözümler gerektirmektedir. Bu noktada evrensel bir kavram olan bilim, uluslararası ilişkilerin ve siyasetin ana damarlarından biri haline gelmiştir. Ülkelerin gelişmişliklerini gösteren en önemli unsurlardan birisi de hemen her disiplindeki bilim toplulukları, bilim insanları, bilim kuruluşları ve tesisleridir. Bugün farklı ülkelerdeki bilimsel gelişmeler, bilgi ve iletişim teknolojileri aracılığıyla dünyaya yayılmaktadır ve bilimsel gelişmelerin sonuçları tüm insanlığı etkilemektedir. Bilim insanları, araştırmaları ve bulgularıyla ülkeler arası muğlak konuları aydınlatabilme ve rasyonel öneriler sunma gücüne sahiptir. "Bilim diplomasisi" kapsamında, başarılı bilimsel çalışmaların sonuçlarını dünyanın kullanımına sunan ülkelerin kendi büyüklükleri, devamlılıları ve itibarları için de önemli bir "yumuşak güç" unsuru olduğu söylenebilir.

Bilim insanlarının ve bilim üreten kuruluşların kamuoyu ile iletişim kurması ve toplumsal katılımın sağlanması söz konusu olduğunda ise "bilim halkla ilişkileri" devreye girmektedir. Bilimsel faaliyetlerin farkına varılması, desteklenmesi ve bu konuda kamuoyunun desteğinin yaratılması için halkla ilişkiler araçları önemli unsurlardır. Bu doğrultuda ulusal ve uluslararası düzeyde yapılan bilim diplomasisi faaliyetlerinin kamuoyuna geniş çaplı duyurulması ve tanıtımasında halkla ilişkiler önemli bir araçtır. Dünyaya kıyasla Türkiye'de bilim diplomasisi ve bilim halkla ilişkileri ilişkisini ele alan çalışmalar oldukça sınırıdır. Bu çalışma ile dünyada en eski bilim diplomasisi kurumları olarak gösterilebilecek The Royal Society (Birleşik Krallık) ve American Association for the Advancement of Science (AAAS)'nin (ABD) faaliyetleri karşılaştırmalı olarak incelenmektedir. Bu doğrultuda bu iki kurumun faaliyetleri üzerinden Türkiye'nin uluslararası akademik ve bilimsel iş birliklerinin artırıması ve tanıtılması amacıyla bir bilim diplomasisi modeli ortaya koyulması amaçlanmaktadır.

\section{Kamu Diplomasisi ve Uluslararası Halkla İlişkiler}

Dünyanın ortak sorunları her geçen gün artarken, bu sorunlar ülkeleri birbirine daha fazla yaklaştırmakta ve daha fazla iş birliğine zorlamaktadır. Bu noktada devreye giren iki kavram "kamu diplomasisi" ve "uluslararası halkla ilişkiler"dir. Temelini bilim, sanat, spor, eğitim, turizm, iletişim gibi yumuşak güç unsurlarından alan kamu diplomasisi ve uluslararası halkla ilişkiler karşılıklı iş birlikleri kurulması, ortak çıkarlarda buluşulması, diyalog ve müzakere ortamlarının yaratıması noktasında son yıllarda önemi artan stratejiler olarak karşımıza çıkmaktadır. Yıllar içinde toplumsal, ekonomik ve teknolojik koşullar doğrultusunda tanımı ve kapsama alanı değişen kamu diplomasisi ve uluslararası halkla ilişkiler her geçen gün farklı fonksiyonlarla yeni boyutlar kazanmaktadır.

Yang vd., (2012, s.653) kamu diplomasisini, bir ulusun başka bir ülkede yaşayan ulus üzerinde olumlu bir imaj geliştirme çabası olarak tanımlarken; Snow'a 
(2014, s.67-71) göre devlet kurumları arasında gelişen ve halkla iletişimin çok az olduğu geleneksel diplomasiye karşın kamu diplomasisi çabaları, şeffaf ve açık kaynaklı olacak şekilde tasarlanmıştır. Yeni kamu diplomasisi sivil toplum kuruIuşları, özel vatandaşlar ve uygulayıcılar arasında halktan halka iletişimle ilgilidir. Aktif ve katılımcı bir halkı içerir, diyalog ve değiş tokuşa odaklanır ve genellikle daha uzun vadeli davranış değişikliği yaratma amacındadır. Sharp $(2005$, s.106) kamu diplomasisini, temsil edilenlerin çıkarlarını ilerletmek ve değerlerini genişletmek için bir ülkenin halkıyla doğrudan ilişkilerin sürdürüldüğü süreç olarak görmektedir. Bose vd.'ne (2020, s.734) göre de kamu diplomasisi geleneksel olarak bir ülkenin dış politikası ile ilgilidir. Dolayısıyla halkla ilişkiler yoluyla hem yabancı ulusların hem de yerel halkın farklı ülkelere/halklara karşı olumlu fikir ve imaj yaratma algısını etkileme niyetini kapsar.

Benzer bileşenlere sahip olan halkla ilişkileri stratejik ilişkiler yönetimi olarak tanımlayan Hutton (1999, s.208) halkla ilişkilerin fonksiyonlarını ikna etme, savunma, bilgi paylaşımı, ilişki inşa etme, imaj yapılandırma ve itibar yönetimi olarak sıralamaktadır. Halkla ilişkileri, iletişim yönetimi çerçevesinde kurum ve hedef kitleleri arasında iletişim köprüsü kurma, iş hedeflerine katkıda bulunma, ortak zemin yaratma çabası olarak tanımlayan Peltekoğlu da (2009, s.10), halkla ilişkilerin fonksiyonlarını uluslararası ilişsilerdeki diplomatik iletişim, sivil toplum örgütlerinin destek çabaları, pazarlama iletişimi, çalışanlarla iletişim, vatandaşların/çalışanların kararlara katılımlarının sağlanması gibi geniş çerçevede ele almaktadır.

Karşılıklı halkların zihin ve kalplerinin kazanılması, ortak çıkarlar etrafında buluşulması, diyalog ve etkileşimli ortamların yaratılması, uzlaşı ve müzakere yoluyla sorunların çözüme kavuşturulması, katılımcılık ve karşılıklı anlayış koşulları yaratılması gibi fonksiyonlar etrafında buluşan kamu diplomasisi ve halkla ilişkiler bugün uluslararası ilişkilerin bir parçası haline gelmiştir. Özellikle teknolojik gelişmeler ve devlet dışı aktörlerin ortaya çıkması (Hocking, 2005; Cowan ve Arsenault, 2008; Zaharna, 2009) kamu diplomasisinin yeniden tanımlanmasını (Melissen 2005; Zaharna ve Uysal, 2015) ve halkla ilişkilerle daha fazla ilişkilendirilmesini (L'Etang ve Pieczka, 2002; Signitzer ve Coombs, 1992) getirmiştir.

Cowan ve Arsenault (2008, s.12) ortaya koydukları kamu diplomasisi modelinde diyalog ve iş birliğini en önemli iki ayak olarak tanımlamaktadırlar. Kelley (2009, s.73) kamu diplomasisini hedef toplumları etkileme, toplumsal katılım/ iş birliği sağlama ve karşııkı bilgilendirme olarak ele almaktadır. Zaharna (2009, s.87) da daha iyi bir uluslararası ilişkiler ortamı yaratabilmek için benzer şekilde bilgi aktarımı ve ilişki/iletişim inşasını kamu diplomasisinin doğal süreci olarak ortaya koymaktadır.

Peisert'in kamu diplomasisi için oluşturduğu modelin bir boyutu ise değiş-tokuş ve iş birliğidir. Bu boyut da ülkelerin karşılıklı olarak çeşitli sosyal, ekonomik, kültürel, bilimsel sorunlara eğilmesi ve ortak çözümler ortaya koyma çabasına işaret etmektedir (aktaran Signitzer ve Wamser, 2009, s.399). Kamu 
diplomasisinin farklı boyutlarını ortaya koyan Nye (2005, s.108), Ross ve Leonard (aktaran Kelley, 2009) ve Szondi'nin (2009) ortak buluşma alanları da "iletişim ve ilişki inşası" olarak karşımıza çıkmaktadır. Toplumları tanıma, onlarla ortak çıkarlarda buluşabilmek için bir diyalog ve etkileşim alanı gerekir ki bunu da kamu diplomasisi ve halkla ilişkiler çabaları çerçevesinde görmek mümkündür.

Üretim, ulaşım ve iletişim teknolojileri ile ivme kazanan küreselleşme ile ülkeler, halklar birbirine daha fazla yaklaşırken uluslararası ilişkilerde devlet-devlet düzeyindeki ilişkiler anlayışından ziyade devlet-halk, halk-halk ilişki boyutları tartışılır olmuştur. Burada devreye giren kamu diplomasisi, sadece üst düzey devlet yetkilileri ile değil aynı zamanda devlet dışındaki aktörler yani düşünce kuruluşları, akademisyenler, bilim insanları, sanatçılar, sporcular, dil-kültür birlikleri gibi sivil oluşumlarla hareket etme prensibindedir. Kavramlar profesyonelleştikçe ve gereksinimler arttıkça kamu diplomasisi ve halkla ilişkiler de bilim diplomasisi, bilim halkla ilişkileri, bilim iletişimi şeklinde özel alanlarla karşımıza çıkmaktadır.

\section{Bilim Diplomasisi}

Dünya artık çok boyutlu ilişkiler ve sistemler üzerinde işlemektedir. İklim, göç, çevresel felaketler, salgın hastalıklar, nükleer silahlanma gibi sorunlarla ülkelerin tek başına mücadele etmesi imkânsız hale gelmiştir. Küreselleşme ve teknoloji ile birlikte zaman ve mekân sorunsalının ortadan kalktığı ancak bir o kadar da tarafların belli olmadığı, belirsizliğin, karmaşıklığın, değişkenliğin hüküm sürdüğü, karışık iş birliklerin yaşandığı bir dönem ortaya çıkarmaktadır. Dolayısıyla insanlık tüm disiplinlerin iç içe geçtiği, süreklilik ve entegrasyon gerektiren bir ortamla karşı karşıya kalmaktadır.

Bilim ve teknoloji, -özellikle de bilgi ve iletişim teknolojileri- ile dünya siyaseti ve uluslararası ilişkilerin birbirini etkilediği üzerinde birçok araştırmacı hemfikirdir (Weiss, 2005; Krige ve Barth, 2006; Rosenau ve Singh 2002). Bilimsel gelişmeler bilgi ve iletişim teknolojileri ile tüm dünyaya hızla yayılmakla birlikte, bilim ve dünya siyaseti arasındaki ilişkinin analizi ve kavramsallaştıııması da bir o kadar zordur. Işte burada devreye giren "bilim diplomasisi" kavramı her iki sorunun da olası cevabı olarak kabul edilebilir.

Kamu diplomasisinin önemli araçlarından biri olan bilim diplomasisi, farklı ülke insanlarının iş birlikleri oluşturmasında ve diplomatik bağların kurulmasında faydalı bir araç haline gelmiştir. Aynı zamanda bilim, barışçıl uluslararası ilişkiler için yeni olanaklar sunarken, devletler de bilim diplomasisinin önemini kavramaya başlamıştır. Bu da yabancı devletlerle bağ kurmanın yeni bir yolu olarak bilim dipIomasisinin ortaya çıkmasıyla sonuçlanmıştır (Sütçü, 2012, s.11).

Colglazier'e $(2018$, s.2) göre modern çağda bilim diplomasisi tam anlamıyla II. Dünya Savaşı'ndan sonra nükleer silahlarla ilgili sorunlar ile başlamıştır. Bilim diplomasisi Sovyet ve Batıı bilim insanları arasında nükleer silahların kontrolünü 
kolaylaştırmada çok etkili olmuştur. Tarihsel olarak bakıldığında, hükümet dışı bilimsel kurumların bilim politikası ve bilim diplomasisi üzerindeki ikili ve çok taraflı angajmanı, son otuz yılda önemli oranda artmıştır. Majumdar $(2018$, s.2) diplomasinin, herhangi bir ülkenin bütçesini aşan ve büyük yatırımlar gerektiren çağdaş araştırmalar için bilimsel iş birliklerinin kurulmasında önemli rol oynayabileceğini ifade etmektedir. Gluckman vd. (2017, s.3) "Küresel intiyaçları ve zorlukları yenmek için tasarlanmış kolektif girişimleri" bilim diplomasisi faaliyetleri olarak tanımlarken; Fedoroff'a (2009, s.10) göre ise diplomasi, bilimin dönüştürücü olabileceği bir politika ve karar verme alanıdır. Turekian vd.'ne göre de (2014, s.4) organik bir çalışma alanı olarak ortaya çıkan bilim diplomasisi, temelde bir ülkenin dış politika hedeflerini ilerletmek ve ülkelerin karşılıklı yararına bilimi kullanmalarını amaçlamaktadır. Yani, uluslararası bilimsel iş birliği bilimsel gruplar tarafından yönetilirken, bilim diplomasisi hem dış politika hem de bilimsel iş birliğinde aktif olan hükümet üyelerinden oluşmaktadır. Ancak yıllar içinde özellikle sağlık sorunları, bulaşıcı hastalıklar, iklim değişiklikleri, kitlesel göçler gibi sorunlar küresel çapta yaşanmaya başlandıkça bilim diplomasisinin kapsama alanı da genişlemektedir. Sorunlar karşısında sadece hükümetler değil, hükümet dışı halk sağlığı uzmanları, üniversiteler, vakıflar, dernekler hatta bireysel çabalar öne çıkmaktadır.

Ancak, iş birliğine dayalı uluslararası ilişkilerin inşasında kullanılmasına rağmen, bilim diplomasisinin etkin bir şekilde gerçekleştirilmesi için iyileştirilmesi gereken çeşitli noktalar vardır. Bilimsel diplomasi ile ilgili bakış açısı ve ona yönelik tutumlardaki eksikliklerin giderilmesi yükü hem devletlerin hem de bilim insanlarının üzerindedir. Bu eksikliklerin giderilmesinde de iletişim ve halkla ilişkiler araçlarının kullanılması bilim diplomasisi faaliyetlerinin etkinliğini güçlendirecek ve dolayısıyla bir dış politika aracı olarak bilim diplomasisinin dayanıklıı̆ını artıracaktır.

Turekian'a $(2018$, s.5) göre bilim diplomasisi geçici değildir. Bilimsel çabanın çoğu planlanmamış etkileşimler tarafından yönlendirilirken, bilim diplomasisinin daha stratejik bir yaklaşımı vardır. Ayrıca bilim diplomasisi kurumlar tarafından yönlendirilir. Bilim diplomasisi hükümetler, üniversiteler, özel sektör ve sivil toplum ile kurumsal düzeyde bir bağlantı gerektirir.

Legrand ve Stone (2018, s.394) bilim diplomasisinin temel aktörlerini ilk sırada Dünya Bankası, BM (Birleşmiş Milletler), Commonwealth (Britanya Milletler Topluluğu) gibi uluslararası kuruluşları; ikinci sırada ulusal sağlık, telekomünikasyon, ulaştırma, enerji, hukuk ve adalet alanlarındaki kamu birimleri ve devlet yetkilileri; üçüncü olarak da devlet dışı aktörler, mesleki kuruluşlar ve bilimsel dernekler şeklinde sıralamaktadırlar.

Anglofon (İngilizce konuşulan ülkeler) dünyasında, "bilim diplomasisi" özel terimi ilk olarak 1990'ların sonlarında ortaya çıkmış ve çok sayıda anlam, gündem, ilişki ve uygulama alanı ortaya koymuştur. Bilim diplomasisi kavramı ilk zamanlarda bilim ve dünya siyaseti arasındaki ara yüzün devlet merkezli yönleriyle eşanlamlı 
hale gelmiş ve dış politika uygulayıcılarının ve AAAS ve The Royal Society gibi bilim kuruluşlarının deneyimleriyle şekillenmiştir (Kaltofen ve Acuto, 2018, s.9).

“Bilim, kültürel, ulusal veya dini geçmişe bakılmaksızın insanlar arasında katılım ve fikir alışverişi için bir iletişim ortamı sağlar. Bilim diplomasisi, bilim ve dış politika topluluklarının çıkarları ve motivasyonları arasındaki ortak yaşamı güçlendirmeyi amaçlar" (AAAS-RS Report, 2010, s.VI). "Fedoroff'a göre bilim diplomasisi, insanlığın karşı karşıya olduğu ortak sorunları ele almak, yapıcı ve bilgiye dayalı uluslararası ortaklıklar kurmak için uluslar arasındaki bilimsel etkileşimlerin kullanılmasıdır" (aktaran, AAAS-RS Report, 2010, s.1).

AAAS ve Royal Society tarafından hazırlanan New Frontiers of Science Diplomacy-2010 raporuna göre "bilim diplomasisi" hala değişken bir kavram olarak tanımlanmakta ancak bilim, teknoloji ve yenilik boyutlarıyla politikaya faydalı bir şekilde uygulanabilmektedir. Rapor, bilim diplomasisi için üç boyut önermektedir (AAAS-RS Report, 2010):

- “Dış politika hedeflerini bilimsel tavsiyelerle bilgilendirmek/ desteklemek (science in diplomacy): Sorunların çözümünde politikacılara yeni bilgilerin, önerilerin sunulması.

- Uluslararası bilim iş birliğini kolaylaştırmak (diplomacy for science): Bilimsel iş birliklerini artırmak ve kolaylaştırmak adına diplomasinin gücünden faydalanmak.

- Ülkeler arasındaki uluslararası ilişkileri geliştirmek için bilim iş birliğini kullanmak (science for diplomacy): Ülkeler arasındaki ilişkileri güçlendirebilmek, sürdürülebilir bir dünya yaratabilmek amacıyla çeşitli bilimsel etkinlik ve platformlar aracılığıyla ortaklıklar ve iş birlikleri kurulması".

Bu tanım ve sınıflandırma, eleştirilmesine rağmen bilim diplomasisi üzerine neredeyse tüm politika tartışmalarında ve literatür çalışmalarında mihenk taşı haline gelmiştir (Smith, 2014, s.825). AAAS ve Royal Society dışında diğer sivil toplum örgütleri; Uluslararası Uygulamalı Sistem Analizi Enstitüsü (IIASA), InterAcademy Ortaklığı (IAP), Uluslararası Bilim Konseyi, WHO, UNESCO gibi kuruluşlar da hükümetlere ve halka danışmanlık yapma, bilim akademileri oluşturma, küresel çapta bilimsel çalışmalar yürütme ve öneriler sunmaya odaklanmışlardır. Hatta artık devletler himayesinde ve devletler dışında bilim danışmanlarının oluşturduğu kuruluşlar da son on yıl içinde yükselişe geçmiştir. ${ }^{1}$

Dünya sorunlarının çözümünde iş birlikleri, ortak anlaşmalar ve sözleşmeler önemli atılımlardır. Ancak asıl önemli olan ise bu kararların uygulanabilir olmasıdır.

1 International Network for Government Science Advice (INGSA), The Bureau of Oceans and International Environmental and Scientific Affairs (OES), The Science and Technology Advisor to the State (STAS), The Office of Science and Technology Policy (OSTP), National Academy of Sciences (NAS), The Global Innovation through Science and Technology (GIST) initiative gibi bilim diplomasisini destekleyen kurum ve kuruluş yer almaktadır. 
Thompson (2018, s.45) dünyada az gelişmiş ya da gelişmekte olan ülkelerin ulusal kalkınma intiyaçlarını karşılamak ve Ar-Ge programları oluşturmak için yeterli bilgi bankalarına, kaynaklara ve yeteneklere sahip olmadıklarını, bu tür ülkelerin genellikle uluslararası bilimsel araştırmaların/kuruluşların bilgi ve ürünlerine güvendiğini ve bunlardan yararlandıklarını ifade etmektedir. Thompson, ancak hayati önem taşıyan uluslararası bilimsel araştırma ürünlerinin her zaman için uygulanabilir veya erişilebilir olmadığına da dikkat çekmektedir.

Bilim diplomasisini aynı zamanda ülkelerin itibarlarını, saygınlıklarını, gelişmişliklerini gösteren yumuşak güç aracı olarak da ele almak gerekir. Çünkü temelindeki kamu diplomasisi ve halkla ilişkilerin, farklı ülkelerin/halkların kalplerinin ve zihinlerinin kazanılması amacı doğrultusunda bilim diplomasisine yeni bir çerçeve çizen Gluckman vd. (2017, s.7) bilim diplomasisi için üç yeni kategori öngörmektedir: "Bir ülkenin ulusal ihtiyaçlarını doğrudan ilerletmek için tasarlanmış eylemler"; "sınır ötesi çıkarları ele almak için tasarlanmış eylemler"; "öncelikle küresel intiyaçları ve zorlukları karşılamak için tasarlanmış eylemler".

Bilimsel bulgular dünya siyasetinde artık daha fazla yer bulmaya başlamıştır. Çalışmalarıyla 1995 Nobel Kimya Ödülü'nü alan Sherwood Rowland (ABD), Mario Molina (Meksika) ve Paul Crutzen (Hollanda) gibi bilim insanları ozon probleminin anlaşılmasına katkıda bulunmuş ve ABD Kongresi'ni sprey kutularında kullanılan ozon tabakasını incelten maddeleri tek taraflı olarak yasaklamaya ikna etmişlerdir. Biyolog George Woodwell ve genç Hintli bir avukat Kilaparti Ramakrishna, BM İklim Değişikliği Çerçeve Sözleşmesi'nin (UNFCCC) taslağının hazırlanmasında diplomatlarla birlikte çalışmışlardır (Moomaw, 2018, s.79). Çok sayıda verilebilecek örnek, bilimin ve bilim insanlarının artık bir diplomat gibi rol aldığını göstermektedir. "Diplomasinin bilimsel amaçlarla kullanılması uluslararası bilimsel ve teknolojik iş birliği kanallarının daha kolay bir şekilde tesis edilmesini sağlar. Bilimsel faaliyetlerin diplomatik amaçlarla kullanılması ise bir ülkenin muhatap kamuoyları nezdinde itibarını ve nüfuzunu artıır" (tasam.org, 2016).

Bilim diplomasisinin kapsama alanı o kadar geniştir ki; ulusal güvenlik ihtiyaçları, silah kontrol anlaşması için gerekli güvenin tesisi ve sürdürülmesi, gıda ve tarımla ilgili alanlar, kalkınma programları, ticaret müzakereleri, fikri mülkiyet, telif hakkı, yazılım ve ileri biyolojik konular, teknoloji ve inovasyon büyük ölçüde bilime bağımlıdır ya da bilimsel çalışmalarla yürütülmektedir (Grimes vd. 2014; Gluckman vd., 2017). Bilim ve politika ilişkisi noktasında Thompson (2018, s.46) politikada bilimin kullanılmasının siyasi söylemi güçlendirebileceğine siyasilerin kararlarında ve seçim süreçlerinde halkın güvenini artırabileceğine değinmektedir.

Her ne kadar siyasiler kendi amaçları için bilimden faydalansalar da bilimin ve bilim insanlarının siyasileşmemesi, bilgileri doğru ve tarafsızca aktarabilmesi son derece önemlidir. Aksi durum bilimi evrensellikten, objektiflikten uzaklaştırır. Sadece siyasileşmesi değil, bilimin magazinsel boyutlarda tartışıır olması da bilimsel bulgulara ve araştırmalara gölge düşürür. Bilgi ve iletişim teknolojilerinin 
gelişen dünyasında bilimsel çalışmaların ve girişimlerin çarpıtılmadan doğru ve sağlıklı bir şekilde aktarıması, bilim diplomasisinin desteklenmesi ise bilim halkla ilişkilerini gerektirmektedir.

\section{Bilim Halkla İlişkileri²}

Teknolojinin, küresel rekabetin, ulusal çıkarların evrimiyle birlikte; birçok ülke artık bilimin gücüne ve rekabet avantajı sağlayabilmek için ikna, çekicilik ve yumuşak güç aracı olarak da iletişimin gücüne inanmaya başlamıştır (Kanagarajan ve Sony, 2020, s.131) Enformasyon toplumunun yükselişi ile birlikte bilimsel faaliyetlerin önemi artmış ve 1970'lerden itibaren dünyada, "bilim iletişimi" önemli bir kavram olarak ortaya çıkmıştır. Bilim iletişimi, bilginin kamuoyuna iletilmesi ve bilime karşı ilginin ve farkındalığın artması amacıyla faaliyet gösteren bir iletişim alanıdır. Bilim iletişimi faaliyetleri, toplumun bilimi anlaması (Public Understanding of Science), toplumun bilimin farkına varması, toplumun bilimle bağlantısı/ bilime katılımı (Public Engagement with Science and Technology) gibi çeşitli yaklaşımlar doğrultusunda değerlendirilmektedir (Burakgazi, 2017, s.235). IIlk kez Thomas ve Durant (1987), günümüzde de halen geçerli olan "halkın bilim anlayışını neden teşvik etmeliyiz?" sorusunu tartışmaya açmıştır. Bu tartışmaların geneline toplumsal katıımın, demokratik bir bilim politikasının bir parçası olup olmayacağı konusu hakimdir (Stigoe, vd.; 2014, s.4). Schafer, bu yaklaşımların farklılıklarının "bilim iletişiminin nasıl yapılanması gerektiği" konusundan kaynaklandığını belirterek günümüzde Batı'da toplumun bilimi anlaması anlayışından toplumun bilime katılımı anlayışına bir geçiş olduğunu öne sürmektedir (2009, s. 475-476). Bu geçiş daha vatandaş odaklı, daha açık, eşitlikçi ve katıımcı bir bilim anlayışı olarak nitelendirilmektedir (Jasanoff, 2003, s.243). Avrupa Halkın Bilime Katılımı Komisyonu da yayınladığı raporda bu geçişi doğrulamakta ve bu konuda birçok bilim insanının toplumla sosyal yansıma ve diyalog halinde bulunduğunu gösteren birçok pratik uygulama örneğinin bulunduğunu ifade etmektedir. Bununla birlikte rapora göre bilim politikası ve araştırması konusunda toplumun söz hakkı olabileceği, bilimsel uygulamayı yönetecek değerler, kodlar ve normlardan oluşan bir yazılıma ihtiyaç vardır (Report of the Science and Society Session, 2007, s.12-16). Entradas ve Bauer (2016, s.16) gerçekleştirdikleri araştırmaya göre bilim üreten kuruluşun büyüklüğ̈̈, halkın katılımına yönelik sahip olduğu fon ve iletişim personelinin istihdamı gibi etkenler kuruluşun faaliyetlerine halkın katılımı konusunda büyük farklılık yaratmaktadır.

Toplumun bilime katılımı anlayışı, bilim üreten kurumları ve bilim insanlarını toplumla güvene dayalı çift yönlü simetrik iletişim modeli doğrultusunda diyalog kurmaya sevk etmektedir. Bu durum karşımıza bilim halkla ilişkileri kavramını çıkarmaktadır. Bilim üreten kuruluşlar toplumla uzun vadeli kamu yararına dayalı etkileşimli bir ilişki kurmak, bilim üretimi süreçlerine toplumun katılımını sağlamak ve buna bağı olarak itibarını yükseltmek için bilim halkla ilişkilerine intiyaç duymaktadır. Bilim üreten kuruluşlar ve bilim insanları kamuoyunu bilgilendirme,

2 Orijinali: Science PR 
bilinçlendirmek ve hedef kitlelerle bağlantı kurmak için öncelikle kitle iletişim araçlarının ilgisini çekmek zorundadır. Aynı zamanda günümüzde üniversiteler ve araştırma kuruluşlarının kendilerini müşterinin ihtiyaçlarını karşılayan ve uluslararası rekabet için modern bir izlenim veren hizmet işletmeleri olarak sunmaları beklenmektedir (Lederbogen ve Trebbe, 2003, s.333). Bu sebeple birçok bilim üreten kuruluşun medya, politikacılar ve geniş halk kesimleriyle iletişim işlevini geliştirmeye yönelik olarak basın, halkla ilişkiler ve iletişim ofisleri bulunmaktadır (Borcheld, 2008, s.145). Bu durum artık ulusal ve uluslararası düzeyde üniversiteler düzeyinde genel bir politika haline gelmiştir (Neresini ve Bucchi, 2011, s.66).

Bilim halkla ilişkileri, bilim kuruluşlarının ve insanlarının söz konusu hedefler doğrultusunda kullandıkları en temel iletişim uygulamalarını içermekte ve bilimsel gelişmeler konusunda ele alınan birçok konuyu başta basın bültenleri olmak üzere birçok halkla ilişkiler aracı ile kamuoyuna aktarmaya çalışmaktadır. Bilim halkla ilişkileri hedef kitleye yönelik olarak sadece bilgilendirme ve bilinçlendirme amaçlı faaliyetler yapmaz, aynı zamanda bilim üreten kuruluşun tüm hedef kitleleri ile uzun vadede iletişim süreçlerini yönetir, kuruluşun tanıtım, lobicilik, kriz iletişimi, imaj ve itibar yönetimi gibi uygulamalarını da gerçekleştirmektedir.

Bilim üreten kuruluşların başında gelen üniversiteler, yeni öğrenci adayIarına yönelik tanıtım yapmak, bilimsel çalışmalarını duyurmak ve bu çalışmalar için çeşitli kuruluşlardan fon/bağış almak, imaj oluşturmak ve sürdürmek, itibar inşa etmek, sivil toplum kuruluşlarının/ yerel yönetimlerin/ kamuoyunun desteğini almak veya bilim karşıtı gruplarla mücadele etmek ve lobi çalışmaları için halkla ilişkiler araçlarını kullanmaktadır (Borcheld, 2008, s.147). Bunun dışında üniversiteler misyonlarının bir parçası olarak, akademisyenleri araştırmalarını yaymaya, topluluklarla ilişki kurmaya ve kamu politikası oluşturma ve tartışmalarına katkıda bulunmaya teşvik eder. Öte yandan üniversite bünyesinde bulunan medya ofisleri üniversitelerdeki konumlarına, büyüklüklerine ve görev alanlarına ve üniversitelerinin özel tarihlerine ve mevcut yerlerine göre farklı şekillerde üniversite hakkında bilgi yayarken, gazeteciler ve akademisyenler arasındaki iletişimi yönetirken değişen düzeylerde gözetim ve düzenleme politikaları uygular (Rowe \& Brass, 2011 , s.5). Türkiye'de de bilim üreten kuruluşların bilim halkla ilişsileri kapsamında en çok basın bülteni, basın toplantıları, dijital kanallar (web sitesi, e-posta, sosyal medya kanalları), festivaller, etkinlikler, sponsorluklar gibi birçok halkla ilişkiler aracını kullandığı görülmektedir.

Özellikle medya ilişkileri konusunda bilimsel gelişmeleri kamuoyuna anlatmak, kamuoyu ile iletişim kurmak ve kamusal görünürlük elde etmek için bilim insanları, bilim halkla ilişkiler uygulayıcılarına ihtiyaç duymaktadır. Bilimsel bilgiyi anlamını bozmadan kamuoyunun anlayabileceği sadelikte metne dökmek oldukça güç bir iştir. Halkla ilişkiler uygulayıcıları bilimsel araştırmaları medya mensuplarının ilgi duyabileceği ve kamuoyunun anlayabileceği biçimde medyaya aktarmayı sağladıkları için halkla ilişkiler uygulayıcıları için "bilgi çevirmenleri"”3

3 Orj: Informed translators 
terimi kullanımaktadır (Lievrouw ve Carley, 1990'dan akt. Duke, 2002, s.312). Özellikle bilim halkla ilişkileri kapsamında yapılan medya ilişkileri, kamu yararı temelli toplumun bilimsel farkındalığını artırmak ve bilime katıımı teşvik etmek için yapııırsa bilim kuruluşları ve bilim insanları ile medya mensupları arasında sağıkı ı bir ilişki kurulmasına yardımcı olan önemli bir faktör haline gelmektedir.

Ülkemizde bilim halkla ilişkileri kavramı konusunda çalışmalar sınırlı sayıda olmasına karşın dünyada bilim halkla ilişkilerinin standartlaşması ve geliştirilmesi için kurulmuş birçok organizasyon bulunmaktadır. Bunlar arasında STEMPRA (Bilim, Teknoloji, Mühendislik ve Illaç Halkla Illişkiler Derneği - 1983) ve NASW (Ulusal Bilim Yazarları Derneği - 1934) öncü kuruluşlar olarak sayılabilir. Bu kuruluşların misyonları incelendiğinde yaptıkları halkla ilişkiler uygulamalarında, bilimsel bilgilerin doğru ve etik bir biçimde aktarılması, bu konuda üyelerin gerekli donanıma sahip olması ve bilim halkla ilişkileri uygulayıcıları ile bilim muhabirlerini bir araya getirmek ve aynı dili konuşmalarını sağlamak gibi amaçlar sıralanmaktadır (stempra.org/uk, 2020; nasw.org, 2020). Ülkemizde özellikle Ortadoğu Teknik Üniversitesi (ODTÜ)'nin bilim halkla ilişkileri konusunda öncü nitelikte (ODTÜ Bilim Kafe, gezici bilim otobüsü, festivaller, şenlikler, açık dersler vb.) çalışmaları bulunmaktadır. Ayrıca rekabet unsurundan ötürü birçok üniversitenin medya ilişkileri, etkinlik yönetimi ve dijital halkla ilişkiler konularında halkla ilişkiler şirketlerinden danışmanlık hizmeti aldığı görülmektedir.

Küresel ilişkilerde bilim iletişimi, uluslararası anlaşmalar ve gelişmelerde bilim ve siyaseti birleştirme özelliğiyle, iş birliği ortamı yaratarak uluslararası rekabeti şiddetlendirme veya hızlandırma potansiyeline sahiptir (Kaltofen \& Acuto, 2018 , s.8). Uluslararası diplomaside bilim iletişimi için sorunları ve olasıııkları ortaya koyan Leach, bilim iletişiminin bilim ve teknolojinin tanıtımından ve pazarlama faaliyetlerine, bilim ve teknoloji eğitimine ve hatta kendi dillerinde ve diğer dillerde temel iletişim becerilerine sahip araştırmacılara yardımcı olan programlara kadar oldukça geniş bir yelpazede değişiklik gösterdiğini ifade etmektedir (Leach, 2015, s.167).

Tablo 1'de Leach, bilim diplomasisi ile ilgili üç yaklaşım kapsamında bilim diplomasisi ve bilim iletişimi ilişkisini göstermektedir. Bu tabloya göre bilim halkla ilişkileri, bilim iletişimi kapsamında bilimi halkın benimseyeceği şekle sokma (bilimin popülerleşmesi) konusunda faaliyet gösteren bir araç olarak ele alınmaktadır. 
Tablo 1: Bilim Diplomasisinin Farklı Boyutları Açısından Bilim Illetişimi ve Bilim Halkla Illişkilerin Rolü (Leach, 2015, s. 165)

\begin{tabular}{|c|c|c|c|}
\hline $\begin{array}{c}\text { Yönler/ } \\
\text { Hareketler }\end{array}$ & Profesyonel Bilim İletișimi & $\begin{array}{c}\text { Bilimi Halkan } \\
\text { Benimseyeceği Şekle } \\
\text { Sokma }\end{array}$ & Bilim İletișimi Politikası \\
\hline $\begin{array}{l}\text { Bilim için } \\
\text { Diplomasi }\end{array}$ & $\begin{array}{l}\text { Bilimde büyük ölçekli } \\
\text { uluslararası işbirliği kurmak } \\
\text { için iletişim kuran } \\
\text { araştımacilar. }\end{array}$ & $\begin{array}{l}\text { Büyük ölçekli } \\
\text { uluslararası projelerin } \\
\text { çıktıları hakkında } \\
\text { farkındalık yaratan halkla } \\
\text { ilişkiler ve gazetecilik } \\
\text { faaliyetlen. }\end{array}$ & $\begin{array}{l}\text { Araştımacılara örgütsel } \\
\text { iletişim, müzakere ve } \\
\text { fikri mülkiyet } \\
\text { konularında beceri } \\
\text { kazandmmaya yönelik } \\
\text { ulusal ginişimler. }\end{array}$ \\
\hline Diplomaside Bilim & $\begin{array}{l}\text { Araştıma organlarının } \\
\text { politika sorunlarını çözmek } \\
\text { için araştımma potansiyelini } \\
\text { iletme, diyaloğu açma ve } \\
\text { bilim ve teknolojinin } \\
\text { düzenlenmesi hakkında } \\
\text { tavsiyelerde bulunma } \\
\text { ginșimlen. }\end{array}$ & $\begin{array}{l}\text { Politika yapıcıları } \\
\text { araştımma sonuçları ve } \\
\text { sonuçları için kilit bir } \\
\text { hedef kitle olarak } \\
\text { hedeflemek. }\end{array}$ & $\begin{array}{l}\text { Araştımacıları politika } \\
\text { yapıcılarla iletişim } \\
\text { kurmaya ve araştımayı } \\
\text { hükümet süreçlerine } \\
\text { yerleştimeye teşvik eden } \\
\text { ulusal ginişimler. }\end{array}$ \\
\hline $\begin{array}{l}\text { Diplomasi için } \\
\text { Bilim }\end{array}$ & $\begin{array}{l}\text { Araştımacıların, } \\
\text { kısıtlamalararağmen ulusal } \\
\text { ayrımlarda işbirlikçilerle } \\
\text { iletişim kuması. }\end{array}$ & $\begin{array}{l}\text { Bilim ve teknoloji } \\
\text { hakkında yüksek düzeyde } \\
\text { genel bilimsel } \\
\text { okuryazarlı, farkındalık } \\
\text { ve diyaloğu teşvik eden } \\
\text { popülerleştime. }\end{array}$ & $\begin{array}{l}\text { Uluslararası işbirliği } \\
\text { kapasitesini artırmak ve } \\
\text { tartışmalı bilim ve } \\
\text { teknoloji hakkında } \\
\text { uluslararası diyaloğu } \\
\text { kolaylaştırmak için } \\
\text { iletişim becerileni, } \\
\text { kültürel programlarve dil } \\
\text { programları yoluyla } \\
\text { uluslararası araştırmalar } \\
\text { için ulusal teşvik ve } \\
\text { destek. }\end{array}$ \\
\hline
\end{tabular}

Birçok ülke, bilim iletişiminin bilim diplomasisinde stratejik bir araç olarak rolünün ortaya çıkmasıyla dışişleri bakanlıkları vb birimlerde bilim danışmanları istihdam etmeye başlamıştır (Gluckman vd., 2017, s.1). Bilim halkla ilişkilerinin bilim diplomasisi ile ilişkisine bakıldığında, her birinin fonksiyonu ve kapsama alanı farklı görünse de uluslararası bilimsel çalışmaların hedefine ulaşmasında her iki sistemin de entegre çalışmaları gerçeği öne çıkmaktadır.

\section{Araştırmanın Amacı ve Önemi}

Türkiye'de kamu/bilim diplomasisi ile ilgili yoğun çalışmalar yapılırken bilim halkla ilişkileri ve bilim diplomasisini birleştiren çalışma sayısı oldukça sınırlıdır. Bu çalışmanın amacı bilim diplomasi ve bilim halkla ilişkilerinin ilişkisi bağlamında bir durum çalışması ${ }^{4}$ sunmak ve Türkiye için bir bilim diplomasisi modeli ortaya koymaktır. Bu analiz çerçevesinde, dünyanın köklü bilim diplomasisi organizasyonları AAAS (American Association for the Advancement of Science) ve Royal Society'in faaliyetleri incelenerek Türkiye için sürdürülebilir ve kalıcı bir bilim diplomasisi organizasyonu için öneriler sunma amacı güdülmektedir.

4 Nicel veya nitel yaklaşımla durum çalışmasında bir birey, bir kurum, bir grup veya bir ortam ele alınabilir. Amaç belli bir duruma ilişkin sonuçları, varolanları ortaya koymaktır (Yıldırım ve Şimşek, 2016, s.73). 


\section{Araştırmanın Evren ve Örneklemi}

Dünya çapında bilim diplomasisi alanında çalışan yüzlerce kurum ve platform bulunmaktadır. Ancak tüm bu yapıların incelenmesi, zaman kısıtlaması olduğu için ve hepsinin bilgilerine ulaşmak mümkün olmadığından, amaçı örneklem ${ }^{5}$ yöntemi ile sadece Avrupa'dan Royal Society ve ABD'den AAAS inceleme kapsamına alınmıştır. Bu kurumların seçilmesinde, kâr amacı gütmeyen en eski iki bilim topluluğu olmaları ve çalışmalarının diğer kurumlara göre kapsamlı olması etkili olmuştur.

Bu iki kurumun bir halkla ilişkiler aracı olarak kurumsal web siteleri üzerinden mevcut faaliyetlerinin incelenmesi bu çalışmanın sınırlılı̆ını oluşturmaktadır. Incelenen kurumlara ilişkin bilgiler kısaca aşağıdaki gibidir:

The Royal Society (RS): The Royal Society kendisini "Birleşik Krallık'ın insanlığın yararına bilimde mükemmelliği teşvik etmeye kendini adanmış bağımsız bilim akademisi" olarak tanımlamaktadır. Kuruluşu 1660'lı yıllara dayanan Royal Society hikayesini, modern bilimin hikayesi ile özdeşleştirmektedir. Topluluğun ilk yılları, bilimin yürütülmesi ve iletişiminde devrim niteliğinde ilerlemeler kaydetmiştir (royalsociety.org, 2020).

Topluluk bilim tarihindeki en temel, önemli ve yaşamı değiştiren keşiflerin bazılarında rol oynamış ve birçok araştırma alanında bilime büyük katkılar sunmuştur. Yayınları ve üyeleri arasında I. Newton, B. Franklin, J. Cook, C. Babbage, P. Chadwick, C. Darwin, A. Einstein, S. Hawking'den bugün J. B. Burnell, S.Wilson ve $T$. Berners-Lee gibi binlerce bilim insanı ve bilimsel çalışma yer almaktadır. “Dernek, mükemmel bilimin yürütülmesi, Birleşik Krallık'taki araştırmacılar için en iyi ortamın kurulması ve uygun şekilde finanse edilmesi için akademi, endüstri, hükümet, parlamento ve ilgili tüm birim ve kurumlarla iş birliğini hedeflemektedir. Kuruluş, Birleşik Kralıı ekonomisine katkıda bulunacak, topluma fayda sağlayacak araştırmacıları, bilimsel ve teknolojik yenilikleri geliştirmeye yönelik tüm çaış̧maları desteklemeyi kendisine misyon edinmiştir. Dernek 2017-2022 stratejik hedefleri arasında ayrıca çeşitli uluslar arasında ortaklıklar kurmayı, uluslararası ilişkileri geliştirmeyi sıralarken; bilimsel anlayışı destekleyen, bilimsel kaliteyi iyileştiren ve küresel sorunları ele alan ortaklıklar ve ağlar kurulması amacıyla uluslararası çalışmalara önem vereceğini de ifade etmektedir. Diğer yandan dernek, toplumdaki farklı gruplarla ve halklarla etkileşim yoluyla, daha geniş kitleleri bilgilendirmeyi ve bu kitlelerin bilimin bir parçası haline getirmeyi amaçlamaktadır" (royalsociety.org, 2020).

1662'de açılışını İngiltere Kralı 2. Charles'ın yaptığı topluluk, neredeyse başından beri kraliyet himayesine sahip olmasına rağmen İngiliz devletinden bağımsız olarak gönüllü bir organizasyon olarak kalmıştır. Topluluk devletten Enerji ve Endüstriyel Strateji Departmanından (BEIS) hibe alırken, bağımsızlığını

5 "Amaçlı örneklem, zengin bilgiye sahip olduğu durumların derinlemesine çalışılmasına olanak vermektedir" (İslamoğlu, 2009, s.183; Yıldırım ve Şimşek, 2016, s.118). 
sürdürmek amacıyla çeşitli vakıflardan, şirketlerden ve bireysel bağışçılardan da destek almaktadır ve bu destekleri de şeffaf raporlar olarak sunmaktadır. (britannica.com/topic/Royal-Society, 2020). Topluluğun 75'i Nobel Ödülü sahibi olmak üzere, yaklaşık 1.700 üyesi vardır.

AAAS (American Association for the Advancement of Science/Amerikan Bilim Gelişimi Derneği): "AAAS, bilim insanları arasında iş birliğini teşvik etme, bilimsel özgürlügü savunma, bilimsel sorumluluğu teşvik etme ve insanlık için bilimsel eğitim ve bilime erişimi destekleme hedeflerine sahip uluslararası kâr amacı gütmeyen bir kuruluştur. AAAS misyonunu "tüm insanların yararına dünya çapında bilim, mühendislik ve yeniliği ilerletmek" şeklinde ifade etmektedir. AAAS (1848), ulusal düzeyde bilim ve mühendisliğin gelişimini desteklemek ve tüm disiplinlerinin çıkarlarını temsil etmek için kurulan bilim organizasyonu olarak kabul edilmektedir. AAAS'ın hedefleri arasında, bilim insanları ve halk arasındaki iletişimi geliştirmek; bilimin bütünlüğünü ve kullanımını teşvik ederek bilim ve teknoloji girişimlerine desteğini güçlendirmek bulunmaktadır. Ayrıca, kamu politikalarında bilimin kullanımını teşvik etmek, bilim ve teknolojide iş gücünü çeşitlendirmek, herkes için bilim ve teknolojide eğitimi teşvik etmek, bilim ve teknolojiye halkın katıımını artırmak, bilimde uluslararası iş birliğini ilerletmek gibi birçok hedef doğrultusunda çalışmalar yapılmaktadır" (aaas.org, 2020).

1847 'de Boston, Massachusetts'te, bir dizi jeolog ve doğa bilimci tarafından kurulan AAAS'ın bugün dünya çapında 91'den fazla ülkeden 130.000'den fazla bireysel üyesi vardır. Tüm ana bilim dallarını temsil eden AAAS, yaklaşık 300 bilimsel topluluk, meslek örgütü ve eyalet ve şehir bilim akademileri ile koordineli olarak çalışmalar yürütmektedir (britannica.com, 2020; Mitcham, 2005, s.64). AAAS'ın en büyük finansman kaynağı $A B D$ hükümeti olmakla birlikte; Howard Hughes Tıp Enstitüsü; John D. ve Catherine T. MacArthur Vakfı; Verizon Vakfı; Rockefeller Vakfı; New York Carnegie Corporation ve Ulusal Bilim Vakfı gibi birçok kurum tarafından da desteklenmektedir (influencewatch.org, 2020).

\section{Araştırma Yöntemi}

Söz konusu iki kurumun faaliyetleri web siteleri üzerinden niteliksel içerik analizi ile karşılaştırmalı olarak incelenmiştir. Bu kapsamda AAAS ve Royal Society'nin ortaya koyduğu "üç bilim diplomasisi boyutu" baz alınarak ana kategoriler oluşturulmuş ve alt bileşenleri doğrultusunda analiz edilmiştir. Bunlara ek olarak bilim halkla ilişkileri de bu analizde dördüncü boyut olarak ele alınmıştır. Buna göre bu boyutlar ve alt bileşenleri aşağıdaki gibidir:

\section{- Dış politika hedeflerini bilimsel tavsiyelerle bilgilendirmek/ desteklemek (diplomaside bilim/science in diplomacy):} Diplomaside bilim, dış politika hedeflerini bilgilendirmek ve desteklemek için gerekli tavsiyeleri sağlamada bilim ve teknolojinin rolünü tanımlar. Diplomaside bilimin işlevi, kaliteli bilimsel 
tavsiyelerin politika yapıcılar tarafından etkili bir şekilde alınmasını sağlamaktır (National Research Council, 2002). Küresel sorunların çözümünde politikacılara yeni bilgiler sunulması, dış politika hedeflerine ulaşılması ve politikaların sağlıklı yürütülebilmesinde bilimsel çalışmaların eklenmesidir (AAAS-RS Report, 2010, s.V-VI).

\section{- Uluslararası bilim iş birliğini kolaylaştırmak (bilim için} diplomasi /diplomacy for science): Bu kavram da uluslararası bilimsel iş birliğinin teşvik edilmesini ifade etmektedir. İş birlikleri artık yalnızca tarihsel, kurumsal veya kültürel bağlantılara dayanmamaktadır. Küresel politika zorlukları, yalnızca bilim ve teknolojiden değil, aynı zamanda ekonomik, sosyal, politik ve davranış bilimlerinden de yararlanılarak bütüncül bir şekilde ele alınmalıdır. Disiplinlerarası iş birliği çok daha önemli hale gelmiştir. Örneğin Covid-19 tedavisinde ortak mücadele için çeşitli ülke ve kuruluşların ortaklıklar ve konsorsiyum oluşturması buna örmek verilebilir (AAAS-RS Report, 2010, s.V-VI):

\section{- Ülkeler arasındaki uluslararası ilişkileri geliştirmek için bilim iş birliğini kullanmak (diplomasi için bilim/science for diplomacy):}

Bilimin, gerginlik durumlarında uluslararası ilişkilerin kurulmasına ve iyileştirilmesine yardımcı olmak için kullanılmasıdır. Bilim, askeri teknolojiler gibi sert güç yeteneklerinin geliştirilmesinde her zaman bir rol oynamıştır. Ancak "science for diplomacy", hem ulusal bir değer hem de ulusal çıkarları aşan evrensel bir faaliyet olarak bilimin "yumuşak gücünden" yararlanır. Bilim festival ve fuarları, bilimsel iş birliği anlaşmaları, eğitim bursları, yeni kurumlar oluşturulması, müzakerelerde akademisyen ve bilim insanlarının arabulucu olarak görev alması, bilim iş birliği anlaşmaları vb. çalışmalar bilim diplomasisi adına ağ kurma ve ortaklıkları teşvik etme mekanizmaları bu kapsamda değerlendirilebilir (AAAS-RS Report, 2010, s.V-VI).

- Bilim Halkla İlişkileri/science public relations: Bilimin diplomaside etkin ve etkili bir rol oynayabilmesi için, bilim adamlarının politikacılara çalışmalarında bilimin rolü ve ihtiyacı hakkında küresel perspektif ve analitik düşünme anlayışı sağlaması ve iki grup arasında güven odaklı açık bir iletişim ve etkileşim süreci gerektirmektedir (Forman, 2015: 2). Bu perspektiften bakıldığında bilim halkla ilişkileri, bilim üreten kuruluşun ve bilim insanının ürettiği bilgiyi ulusal ve uluslararası düzeyde topluma aktarmak ve toplumla bağlantı kurmak için yararlandığı iletişim yöntemi olarak tanımlanabilir. Ayrıca bilim halkla ilişkileri, bilim üreten kuruluşların/ bilim insanlarının tüm paydaşlarıyla güven temelli ilişki kurması için gerekli olan temel bir 
iletişim alanı olarak konumlanmaktadır. Bu bağlamda tüm halkla ilişkiler araçlarını kullanılarak bilimin kamuoyuna anlaşılabilir bir şekilde aktarımı ve kamuoyunun bilim süreçlerine aktif olarak katıımı sağlanmaktadır.

\section{Elde Edilen Bulgular}

Seçilen iki kurumun kurumsal web siteleri niteliksel içerik analizi yöntemi ile ele alınmış, kurumların faaliyetleri belirtilen boyutlar dahilinde incelenmiştir.

\section{The Royal Society}

Royal Society'nin (Tablo 2) çalışmalarının kapsamlı ve çok yönlü olduğu görülmektedir. Örneğin bunlardan biri olan "Halk Etkinlikleri" halka açık şekilde gerçekleştirilen etkinliklerdir. Bu faaliyetler bilim diplomasisinin önemli ayaklarından birisi olan toplumsal katıımı destekleyen, alanında uzman kişilerin katıldığı söyleşiler şeklinde olup halkın da etkileşim içinde olabileceği etkinliklerdir. Bu faaliyetlere Stephen Fry ve Venki Ramakrishnan ile bir akşam; Antoine Petit ve Martin Stratmann ile görüşmeler gibi toplantılar örnek verilebilir. "Bilimsel toplantılar" adı altında çevrim içi ve çevrim dışı gerçekleşen bu etkinlikler yine halka da açık olup farklı konular etrafında sürdürülen toplantılardır. "Online Çevrimiçi Yaz Bilim" etkinlikleri de halka açık, etkileşimli online/offline etkinliklerdir (royalsociety.org, 2020)

The Royal Society'de burs olarak çok sayıda bilimsel desteğin verildiği görülmektedir. Yaklaşık 20 farklı burs çeşidi gözlenmiştir. Dünyanın çeşitli bölge ve bilim insanlarını kapsayan bursların hem ülkeler arasındaki sorunların çözümünde, hem bilimin gelişiminde, iş birliği ve ortaklıklar kurmada hem de bilimsel halkla ilişkilerin gelişiminde önemli rol oynadığı görülmektedir. Örneğin; endüstri bursları, sektörler arasında endüstri ve akademiden yetenekli bilim insanlarının ve mühendislerin hareketliliğini sağlamaktadır. Royal Society Wolfson Misafir Bursu, uluslararası iş birlikçi bağlantıları teşvik etme ve ev sahibi kuruluşta ve daha geniş kapsamlı bilimsel araştırmaları zenginleştirme fırsatı sunmaktadır. 
Tablo 2 : The Royal Society Bilim Diplomasisi ve Bilim Halkla illişkileri

\begin{tabular}{|c|c|c|c|}
\hline \multicolumn{4}{|c|}{ The Royal Society } \\
\hline Diplomaside Bilim & Bilim için Diplomasi & Diplomasi için bilim & Bilim Halkla ilişkileri \\
\hline Hibeler (Burslar) & Hibeler (Burslar) & Bilimsel toplantılar & Halka açık olaylar \\
\hline Ödüller & Ödüller & Online Çevrimiçi Yaz Bilimi & Bilimsel toplantılar \\
\hline Eğitim, rehberlik ve ortaklık & Küresel Yetenek Vizesi & Sen ve gezegen & Online Çevrimiçi Yaz Bilimi \\
\hline Tüm projeler & Tüm projeler & Hibeler (Burslar) & Sen ve gezegen \\
\hline Brexit ve Ingiltere bilimi & Uluslararası Çalışma & Ödüller & Hibeler (Burslar) \\
\hline \multirow[t]{14}{*}{ Uluslararası Çalışma } & & Eğitim, rehberlik ve ortaklık & Ödüller \\
\hline & & Flexi-Grant ${ }^{\ominus}$ & Eğitim, rehberlik ve ortaklık \\
\hline & & Tüm projeler & Flexi-Grant ${ }^{\ominus}$ \\
\hline & & Tüm raporlar ve yayınlar & Tüm projeler \\
\hline & & Koleksiyonlar & Tüm raporlar ve yayınlar \\
\hline & & Tüm dergiler & Tüm dergiler \\
\hline & & Yazarlar & Yazarlar \\
\hline & & Kütüphaneciler & Kütüphaneciler \\
\hline & & Ücretsiz içerik & Ücretsiz içerik \\
\hline & & Dijital kaynaklar & Koleksiyonlar \\
\hline & & Araștırma projeler & Dijital kaynaklar \\
\hline & & Uluslararasıı çalıșma & Araştırma projeler \\
\hline & & Fonlar ve finans & Fonlar ve finans \\
\hline & & & Yenilikler/Ne var ne yok \\
\hline
\end{tabular}

FLAIR (Future Leaders - African Independent Research) Bursları alanlarında lider olma potansiyeline sahip, yetenekli Afrikalı genç araştırmacılar içindir. Diğer bursların bazılarını şöyle sıralamak mümkündür: Dorothy Hodgkin Bursu, Royal Society Wolfson Bursu, İkamet Eden Yabancı Girişimci Bursu, Newton Uluslararası Bursları, STEM (Fen, Teknoloji, Mühendislik ve Matematik) vb (royalsociety.org, 2020).

Benzer şekilde bilimin gelişimi ve bilimsel çalışmaların teşviki için The Royal Society çok sayıda farklı alanlarda (Fen/sosyal bilimler, teknoloji vb) ödüller vermektedir. Çok sayıda ödülden birkaçı şunlardır: Apex ödülleri; bilim, mühendislik ve sosyal bilimler ve beşeri bilimler şeklinde disiplinler arasında iş birliğini teşvik etmek amacıyla verilirken; Royal Society Africa Ödülü, bilime yenilikçi katkıda bulunan Afrika merkezli araştırmaları ve bilim insanlarını ödüllendirmektir. Copley Madalyası Topluluğun en eski ve en prestijli ödülüdür (royalsociety.org, 2020).

"Eğitim, rehberlik ve ortaklık" programları ise Birleşik Krallık'taki bilim topluluklarını destekleyip ve finansman, eğitim ve rehberlik yoluyla bilimde mükemmelliği teşvik etmektedir. Ayrıca bu program, bilim insanları ile hükümet ve endüstri arasındaki ilişkilerin geliştirilmesine yardımcı olmaktadır. Öte 
yandan herkesin bilimle iç içe olması, her kesimden insanın bilimsel faaliyetlerle yakınlaşması için çalışmalar yürütmektedirler. Bu programlardan bazıları da şöyledir: Royal Society Okulları Ağı, halkın katılımı için iletişim becerileri, bağımsız araştırmacılar için halkın katıımı, bilim insanlarıyla tanışma, medya becerileri eğitimi, inovasyon ve bilim kursları, mentorluk programı vb. (royalsociety.org, 2020).

Site içinde akademik olarak birçok rapor, proje, araştırma ve makale süreç ve sonuçları da yer almaktadır. "Tarım ve gıda", "ekonomi ve kalkınma", "enerji, çevre ve iklim", "sanayi ve yenilik", "düşük karbonlu enerji programı", "dijital teknoloji ve gezegen" vb. konularında çok sayıda rapor ve proje süreç ve sonuçları yer almaktadır.

Royal Society'nin açık erişimli, uluslararası hakemli dergileri de yüksek kalitede bilimsel yayınlar sunmaktadır. Royal Society, tüm bilimsel disiplinleri kapsayan süreli/süresiz hakemli dergiler yayınlarken, bilimsel bulguların ve fikirlerin yayılması, keşfi ve korunmasını da misyon edinmektedir. İlk kez 1665 'te yayınlanan Philosophical Transactions halen yayınlanan dünyanın en eski süreli bilimsel yayınıdır. Cemiyetin herkese açık erişim sunan dergi portföyü tüm bilim ve bilim tarihini kapsamaktadır. Ayrıca "Kütüphane ve Arşivler"de, binlerce bilimsel illüstrasyonunu, fotoğrafını, el yazmasını ve kitabı dijitalleştirmiş ve halkın erişimine ücretsiz olarak sunmaktadır. Tüm bu yayınlar ve halka ulaşımı da bilim diplomasisi ve bilim halkla ilişkileri için önemli kaynaklardır. Royal Society, bilim tarihi ve ilgili disiplinlerdeki akademik araştırmacıları desteklemekte ve genellikle Sanat ve Beşeri Bilimler Araştırma Konseyi (AHRC) tarafından finanse edilen aktif araştırma projelerine ev sahipliği yapmaktadır (royalsociety.org, 2020).

Uluslararası çalışmalar konusunda da Commonwealth (Britanya Milletler Topluluğu) küresel bilim topluluğunun önemli bir bölümünü oluşturmaktadır. Dernek, bilim insanları arasında ortaklıklar geliştirmeye yardımcı olup dünyanın dört bir yanından bilim insanlarını ve politika yapıcıları bir araya getirmeye çalışmaktadır. Politik karar vericilere küresel konularda tavsiyelerde bulunmak için topluluk üyeleri ve yabancı üyeler de dâhil olmak üzere uluslararası bilim insanlarının uzmanlıklarını tüm dünyaya yaymaktadır. Sitede yer alan blog yazıları, günlük haberler/olaylar, Covid-19 gelişmeleri ile de halkla anlık ve güncel iletişim sağlanmaktadır.

Royal Society'nin, çeşitlilik, eğitim, hibeler, bilim tarihi, sanayi, uluslararası iş birlikleri, akademik-bilimsel yayınlar, bilimsel toplantılar, halk katıımı ile bilim diplomasisinin üç temel taksonomisine uygun faaliyetler yürütmekle birlikte, bilim halkla ilişkileri konusunda da kayda değer çalışmalar yaptığı görülmektedir (royalsociety.org, 2020). 


\section{American Association for the Advancement of Science/Amerikan Bilim Gelişimi Derneği (AAAS)}

AAAS'ın web sitesi incelendiğinde tüm faaliyetlerin dokuz ana başlık altında sıralandığı görülmektedir. Söz konusu ana başlıkların altında sıralanan alt faaliyetler incelendiğinde içerik analizine konu olan dört boyuta da uygun faaliyetler yapıldığı görülmektedir (Tablo 3).

İlk başlık olan "Kanıt Savunuculuğu" faaliyetleri genel olarak Diplomaside Bilim yaklaşımı kapsamında gerçekleştirilmektedir. Örneğin, "Kamu Hususlarında Kanıt Savunuculuğu" başlığı altında kamu kararlarını desteklemek için kamu kuruluşları temsilcilerine açık, özel ve zamanında bilimsel kanıtlar konusunda bilgi sağlama ve politika oluşturma sürecini güçlendirme amaçlı faaliyetler yapılmaktadır. Aynı başlık altında bulunan "Bilim Adamlarını ve Mühendisleri Politikaya Dahil Etme" (ESEP) projesi, hükümetin her düzeyinde (uluslararası, federal, eyalet ve yerel) politika oluşturma sürecine etkin bir şekilde katılmaları için bilim insanlarını ve mühendisleri güçlendirmek adına bir araya gelen kuruluşların bir ittifakıdır. AAAS bünyesinde bulunan "Devlet Ilişkileri Ofisi", güncel bilim ve teknoloji konularında ABD Kongresine zamanında, objektif bilgi sağlar ve bilim ve mühendislik topluluğunun yasa koyucularla etkili bir şekilde çalışmasına yardımcı olur. Bu başlık altında bulunan "Bilim ve Teknoloji Politikası Bursları" ise günümüzün en acil toplumsal zorluklarını ele almak için bilgi ve becerilerini kullanan seçkin bilim insanlarına ve mühendislere, federal politika yapma hakkında ilk elden bilgi amacını taşımaktadır. AAAS bünyesinde bulunan "Bilim, Politika ve Toplum Programları Ofisi" (OSPSP) dört boyuta da uygun faaliyetler göstermektedir. Ofis, bilim ve bilim insanlarını STEM eğitimi, hükümet, işgücü kapasitesi, din ve hukuk dahil olmak üzere birçok toplulukla birleştirmektedir. Bilimsel araştırmaya yatırım konusunda kamu kuruluşlarına tavsiyelerde bulunmaktadır. Toplumun hizmetinde bilimin rolünü geliştirmek amacıyla seminerler, kurslar, ödüller ve açık dersler gibi bilim halkla ilişkileri araçları yoğun şekilde kullanılmaktadır. Burada dikkat çeken bir husus da derneğin özel şirketlerle olan iş birlikleridir. Örneğin çocuklar ve genç yetişkinler için bilim kitaplarının en iyilerine Subaru marka araba ödülü verilmektedir. Subaru, kurumsal web sitesinde "Subaru loves learning6" sloganı ile AAAS ile olan faaliyetlerini kurumsal sosyal sorumluluk faaliyetleri olarak duyurmaktadır. Yine L'Oréal şirketi ABD'de on altıncı yılını kutlayan Bilimde Kadınlar İçin programı, araştırma ve kariyerlerini ilerletmeleri için 80 doktora sonrası kadın bilim insanına 4 milyon doların üzerinde hibe vermiştir (aaas.org, 2020).

STEM'de kariyer bașlığı altında yer alan faaliyetler kapsamında ise bilim insanları, AAAS eğitimlerinden ve halk katılımı, iletişim, ağ oluşturma, bilim politikası ve daha fazlası hakkındaki kurslardan yararlanarak kariyerlerini geliştirebilme imkanına sahiptir. Diplomasi için Bilim ve Bilim Halkla Illişkileri kapsamında ele alınabilecek olan bu çalışmalar arasında yukarıda bahsedilen "Bilim, Politika ve Toplum Programları Ofisi" nin faaliyetleri geniş yer kapsamaktadır. "Çeşitlilik,

6 Bkz. https://www.subaru.com/education/education-causes.html 
Eşitlik ve Kapsayıcılık" başığı altında çeşitli burs programlarının yanı sıra konferanslar, öğrencilerin inovasyon programlarına katıımını teşvik amaçlı çeşitli faaliyetler, halkla açık seminerler, toplantılar bulunmaktadır. Bu başlık altında yer alan "Bilim, Etik ve Din Üzerine Diyalog" (DOSER) projesinin amacı bilim, teknoloji ve toplum konularında bilimsel ve dini topluluklar arasında diyaloğu kolaylaştırmaktır. Proje, bilim insanlarının kamusal katıım için kültürel ve dini olarak kapsayıcı stratejiler ve beceriler geliştirmelerine yardımcı olmaktadır. Halkla ilişkiler aracı olarak sempozyum, seminerler, atölyeler, paneller, kampüs etkinlikleri, ücretsiz halkla açık etkinlikler, yarışmalar, çalıştaylar kullanılan projede, dini liderlere bilimsel konularda rehberlik ve kaliteli bilim kaynaklarının sağlanması, ilgi çekici bilim insanları konusunda yapılan etkinlikler, dini liderlerin bilimle olan ilişkilerini artırmayı amaçlayan bilim eğitimi gibi uygulamalar dikkat çekmektedir. DOSER projesi kapsamında din muhabirlerine yönelik "Bilimi Din Muhabirlerinin Önüne Getirmek" başlığı altında paneller, toplantılar ve ödül programı oluşturulmuştur. Ayrıca projenin videolar, yazılı bültenler gibi herkesin kullanımına açık zengin bir kaynak koleksiyonu bulunmaktadır (scienceforseminaries.org/, 2020). Aynı başlık altında yer alan "SEA Değişim Ödülleri", kolejler ve üniversiteler, fon sağlayıcılar, iş ve endüstri ve çeşitliliğe bağlı diğer paydaşları çevrimiçi ve yüz yüze eğitimler, toplantılar ve kurslar ile bir araya araya getirerek STEM yetenek havuzunu beslemek için iş birlikleri oluşturmayı amaçlamaktadır (aaas.org/, 2020).

"Insan Hakları, Hukuk ve Etik" başlığı altında Diplomasi için Bilim/ Bilim halkla ilişkileri yaklaşımı çerçevesinde özellikle "Nöbetçi Bilim İnsanları" projesi dikkat çekmektedir. 11 farklı alanda 68 ülkeden 1350 gönüllü, tüm bilimsel disiplinlerden bilim insanının dâhil olduğu proje aracılığıyla insan hakları kuruluşları, çalışmalarını geliştirmek için teknik yardıma erişim elde etmekte ve bilim insanları, insan haklarına katkıda bulunarak, bu hakları daha iyi anlama fırsatına sahip olmaktadır. Web sayfasında insan hakları projelerini desteklemek için gönüllü üye olma olanağı ve Romanya, Çin gibi ülkelerde gerçekleşen birçok proje örneği bulunmaktadır. Yine bu başlık altında bulunan "Bilimsel Sorumluluk, İnsan Hakları ve Hukuk Programı" (SRHRL) bilimin, toplumun yararına olacak şekilde uygulanmasını teşvik eder ve kolaylaştıır. Bu başlık altında bulunan "Ekonomik, Sosyal ve Kültürel Haklar Uluslararası Sözleşmesi"nin (ICESCR) 15. maddesini desteklemeye ve bilim insanlarını bu çabaya dâhil etmek için hayata geçirilen "İnsanın Bilim Hakkı" projesi "Bilimsel Sorumluluk, İnsan Hakları ve Hukuk Programı"nın bir parçası olarak devam etmektedir. Diğer başlık "Toplumsal Katıım" başlığıdır. Burada ise kamu ile ilişkileri kurma ve sürdürme amacıyla yapılan bilim halkla ilişkileri faaliyetleri dikkat çekmektedir. Örneğin, 2010 yılından beri yapılan ABD Bilim ve Mühendislik Festivali, AAAS Kolokyum, Derneğin New York'taki galerisinde yapılan sanat etkinlikleri, sergiler; karmaşık bilimsel bilgileri bilim insanlarına, gazetecilere, politikacılara ve halka etkin bir şekilde anlatmak için yapılan "Bilim İletişimi Atölyeleri" başarılı bilim halkla ilişkileri uygulamaları olarak kamuoyu ile paylaşılmaktadır. AAAS 2008 yılından bu yana 8500'den fazla bilim insanı ve mühendise 275 atölye gerçekleştirmiştir. Bununla birlikte "Kamusal Katılım için Bilim ve Teknoloji Merkezi", bünyesinde bilim iletişimi üzerine araştırmalar yapılmakta, 
değişim teorisi adı altında, kamusal katılım için kendi modellerini kamuoyuna sunmaktadırlar (aaas.org/, 2020).

Merkez ayrıca atölyeler, bilim aile günleri, blog, çevrimiçi etkinlikler gibi birçok halkla ilişkiler aracını kamuoyu ile etkileşim için verimli bir şekilde kullanmaktadır.

Tablo 3: AAAS Bilim Diplomasisi ve Bilim Halkla Illişkileri

\begin{tabular}{|c|c|c|c|}
\hline \multicolumn{4}{|c|}{ AAAS } \\
\hline Diplomaside Bilim & Bilim için Diplomasi & Diplomasi için Bilim & Bilim Halkla iliş̧kileri \\
\hline $\begin{array}{l}\text { Kamu Hus uslarında } \\
\text { Kanıt Savunuculuğu }\end{array}$ & $\begin{array}{l}\text { Bilim, Politika ve Toplum } \\
\text { Programları Ofisi }\end{array}$ & $\begin{array}{l}\text { NSF Robert Noyce Öğretmen bursu } \\
\text { programı }\end{array}$ & $\begin{array}{l}\text { NSF Robert Noyce Öğretmen bursu } \\
\text { programı }\end{array}$ \\
\hline Bilirkişi Seçimi & & L'Oréal USA For Women in Science & L'Oréal USA For Women in Science \\
\hline $\begin{array}{l}\text { Bilim Adamlarını ve } \\
\text { Mühendisleri Politikaya } \\
\text { Dahil Etmek (ESEP } \\
\text { Projesi) }\end{array}$ & & $\begin{array}{l}\text { ARISE - Yüksek íhtiyaç Duyulan } \\
\text { Okul Bölgelerindeki Öğretmen } \\
\text { Adaylarının STEM Eğitiminde } \\
\text { Araştırma ve Yeniliğin } \\
\text { Geliştirilmesi } \\
\end{array}$ & $\begin{array}{l}\text { ARISE - Yüksek intiyaç Duyulan } \\
\text { Okul Bölgelerindeki Öğretmen } \\
\text { Adaylarının STEM Eğitiminde } \\
\text { Araştırma ve Yeniliğin } \\
\text { Geliştirilmesi }\end{array}$ \\
\hline Devlet Iliş̧kileri Ofisi & & $\begin{array}{l}\text { Bilim, Politika ve Toplum } \\
\text { Programları Ofisi }\end{array}$ & $\begin{array}{l}\text { Bilim, Politika ve Toplum } \\
\text { Programları Ofisi }\end{array}$ \\
\hline $\begin{array}{l}\text { Bilim, Politika ve } \\
\text { Toplum Programları } \\
\text { Ofisi }\end{array}$ & & $\begin{array}{l}\text { STEM'de Gelişen Araştırmacılar } \\
\text { Ulusal Konferansı }\end{array}$ & $\begin{array}{l}\text { STEM'de Gelişen Araştır macılar } \\
\text { Ulus al Konferansı }\end{array}$ \\
\hline \begin{tabular}{|l|} 
Bilim ve Teknoloji \\
Politikası Bursları
\end{tabular} & & $\begin{array}{l}\text { HBCU Yapımı ve İnovasyon } \\
\text { Girişimi }\end{array}$ & HBCU Yapımı ve İnovasyon Gir işimi \\
\hline \begin{tabular}{|l} 
Bilim ve Mühendislik \\
Diasporaları \\
\end{tabular} & & AAAS S-STEM Girişimi & AAAS S-STEM Girişimi \\
\hline $\begin{array}{l}\text { Uluslararası Iliş̧kiler } \\
\text { Ofisi }\end{array}$ & & $\begin{array}{l}\text { Bilim, Etik ve Din Üzerine Diyalog } \\
\text { (DOSER) }\end{array}$ & $\begin{array}{l}\text { Bilim, Etik ve Din Üzerine Diyalog } \\
\text { (DOSER) }\end{array}$ \\
\hline $\begin{array}{l}\text { Araştırma Rekabet } \\
\text { Edebilirlik Programı }\end{array}$ & & SEA Değişim Projesi & $\begin{array}{l}\text { Bilim Haberciliği Stajında Farklı } \\
\text { Sesler }\end{array}$ \\
\hline & & $\begin{array}{l}\text { Mahkemeye Atanan Bilimsel } \\
\text { Uzmanlar (CASE) }\end{array}$ & Giriş Noktası \\
\hline & & Näbetçi Bilim Ada mları & SEA Değişim Projesi \\
\hline & & $\begin{array}{l}\text { Bilimsel Sorumluluk, İnsan } \\
\text { Hakları ve Hukuk Programı }\end{array}$ & $\begin{array}{l}\text { Mahkemeye Atanan Bilimsel } \\
\text { Uzmanlar (CASE) }\end{array}$ \\
\hline & & Bilimve Insan Hakları Koalisyonu & $\begin{array}{l}\text { Bilims el Sorumluluk, Insan Hakları } \\
\text { ve Hukuk Programı }\end{array}$ \\
\hline & & Insanın Bilim Hakkı & Bilim ve Insan Hakları Koalisyonu \\
\hline & & AAAS Arşivleri & Ins anın Bilim Hakkı \\
\hline & & $\begin{array}{l}\text { Kitle Íletişim Bilimi ve } \\
\text { Mühendisliği Bursu }\end{array}$ & AAAS Arşivleri \\
\hline & & $\begin{array}{l}\text { Bilim ve Teknolojiyle Kamusal } \\
\text { Katlım Merkezi }\end{array}$ & $\begin{array}{l}\text { Kitle Illetişim Bilimi ve } \\
\text { Mühendisliği Bursu }\end{array}$ \\
\hline & & $\begin{array}{l}\text { Leshner Liderlik Bilime Kamusal } \\
\text { Katlım Ens titüsü }\end{array}$ & $\begin{array}{l}\text { Bilim ve Teknol ojiyle Kamusal } \\
\text { Katılım Merkezi }\end{array}$ \\
\hline & & Bilim Diplomasisi Merkezi & Kamu Programları Ofisi \\
\hline & & Sinıfta Bilim & Mühendislik Fes tivali \\
\hline & & STEM Gönüllü Programı & AAAS Kolokyum \\
\hline & & AAAS Sınıfta Bilim Günleri & Bilim ve Teknoloji Sanatı Programı \\
\hline & & Project 2061 & illetişim Bilimi Atölyeleri \\
\hline & & STEM Ë̆itim Programları & Merkez Araştırmaları \\
\hline & & & $\begin{array}{l}\text { Les hner Liderlik Bilime Ka musal } \\
\text { Katılım Enstitüsü }\end{array}$ \\
\hline & & & Bilim Diplomasisi Merkezi \\
\hline & & & $\begin{array}{l}\text { AAAS-Lemelson Buluş El çileri } \\
\text { Programı }\end{array}$ \\
\hline & & & Eğitim ve Insan Kaynakları \\
\hline & & & GSK Yazın Bilim Projesi \\
\hline & & & Sinfta Bilim \\
\hline & & & STEM Gönüllü Programı \\
\hline & & & AAAS Sınıfta Bilim Günleri \\
\hline & & & $\begin{array}{l}\text { Lisans STEM Eğitimi (IUSE) Girişimi } \\
\text { Geliştirme Web Sitesi }\end{array}$ \\
\hline & & & Project 2061 \\
\hline & & & Science Netlinks \\
\hline & & & STEM Ë̆itim Progr amları \\
\hline & & & $\begin{array}{l}\text { Bilim ve Mühendislikte } \\
\text { Sa vunuculuğun Katalizörl üğüu } \\
\text { Çalıştayı }\end{array}$ \\
\hline
\end{tabular}


Bilim Diplomasisi başığı altında "Bilim Diplomasisi Merkezi" faaliyetleri dikkat çekmektedir. Merkez, bilim ve diplomasi arasındaki daha yakın etkileşimler yoluyla topluluklar, toplumlar ve uluslar arasında köprüler kurmayı ve ulusal/küresel zorlukları ele almak için bilimin dış politikadaki rolünü yükseltmeyi amaçlamaktadır. Merkez, tarihi boyunca, bilimsel iş birliği olasılığını keşfetmek için ABD ile Küba, Kuzey Kore gibi zorlu diplomatik ilişkilerin olduğu çeşitli diğer ülkelerle bilimsel anlaşmalar başlatmış veya kolaylaştırmıştır. Bunun yanında merkez bünyesinde hakemli dergi, bilim diplomasisi kursu, bilim diplomasisi ve liderlik çalıştayı, bilim diplomasisi eğitim ağı, çevrimiçi bilim diplomasisi kursları gibi birçok etkinlik yapılmaktadır. Bu başlık altında "Diplomaside Bilim" yaklaşımına uygun olarak faaliyet gösteren "Bilim ve Mühendislik Diasporaları ve Uluslararası Ilişkiler Ofisi" faaliyetleri gerçekleşmektedir.

Diğer başlık "Bilim Eğitimi" faaliyetleri olarak sınıflandııımıştır. Bilim Halkla illişkileri ve Diplomasi için Bilim/Bilim Halkla Illişkileri olarak nitelendirebileceğimiz faaliyetler çocukları bilime dâhil etme amaçlı yaz okulu, sınıfta bilim, STEM öğretmenlerinin eğitimi, bilim okuryazarlığı gibi birçok etkinliği kapsamaktadır.

Son başık olarak "Bilim Politikasını Şekillendirme"de tüm boyutlara uygun olarak 11 ayrı birimde faaliyet yapılmaktadır. Örneğin 1996'dan beri süren "Araştırma Rekabet Edebilirlik Programı" (RCP), hükümetler, üniversiteler, vakıflar ve diğer STEM kuruluşları için stratejik değerlendirme, meslektaş değerlendirmesi, eğitim ve inovasyon ve girişimcilik programları sağlamak için çalışmaktadır.

Görüldüğü üzere AAAS bünyesinde bulunan birimler tarafından gerçekleştirilen birçok proje kapsamında, dört yaklaşımı da kullanarak özellikle iş birliği, bilimsel özgürlük, bilimsel sorumluluk ve tüm insanlığın yararı için bilimsel eğitim ve bilimsel erişim için faaliyet göstermektedir. Bu faaliyetlerin çoğunda ise bilim halkla ilişkileri araçlarını yoğun olarak kullanmaktadır.

\section{Değerlendirme ve Türkiye Bilim Diplomasisi İçin Model Önerisi}

Türkiye'de bilim diplomasisi konusunda örnek bir model oluşturabilmek için öncelikle bilimle ilişkili kurumlar incelenmiştir. Türkiye'de konuyla ilgili olarak Dışişleri Bakanlığı'nın yanı sıra Bilim, Sanayi ve Teknoloji Bakanlığı, Kalkınma Bakanlığı, Milli Eğitim Bakanlığı, YÖK, TÜBiTAK, Türkiye Bilimler Akademisi (TÜBA), Yurtdışı Türkler ve Akraba Toplulukları Başkanlığı, Türk İşbirliği ve Koordinasyon Ajansı Başkanlığı (TiKA), İslam Ülkeleri İstatistik, Ekonomi, Sosyal, Araştırma ve Eğitim Merkezi, üniversiteler, teknokentler ve AR-GE merkezleri bilimsel çalışmalar, ortaklıklar ve iş birlikleri gerçekleştirmektedir (aa.com.tr, 2020). Bu kurumların web siteleri incelenmiş ancak salt "bilim diplomasisi" faaliyetlerinde bulunan özerk bir kurum yapısına rastlanmamıştır. Bununla birlikte bilim diplomasisi alanında uluslararası iş birliğini geliştirmek, akademik alanda uluslararası faaliyetleri, akademik ve bilimsel iş birliklerini artırmak ve tanıtmak amacıyla Yunus Emre Enstitüsü (YEE) ve Türkiye Bilimsel ve Teknolojik Araştırma Kurumu (TÜBiTAK) 
iş birliği ile 2016'da Türkiye Bilimsel ve Akademik İş Birliği Projesi (TABIP) hayata geçirilmiştir. TABIP bilim diplomasisi konusuyla ilgili olarak atılmış çok önemli bir adım olmakla birlikte "ilk sorun" bunun bir "proje" olarak yapılandırılmasıdır. TABIP için, 43 ülkede 54 kültür merkezi ve dünyada 139 irtibat noktasına sahip YEE'nin gücünden faydalanma hedefi, önemli bir başlangıç noktasıdır. Bununla birlikte, Türkiye'nin bilim diplomasisi faaliyetlerinin ayrı bir yapı olarak "kurumsallaşması", incelenen örneklerde olduğu gibi bilimsel gelişmelerin istikrarlı biçimde hem ulusal hem uluslararası toplumların faydasına sunulması gerekmektedir. Bu sebeple vizyon ve misyonunda; "Türkiye'nin akademik ve bilimsel kapasitesini dünyaya tanıtmak, akademik ve bilimsel iş birlikleri kurarak bilim diplomasisi faaliyetleri yürütmek, Türkiye'deki akademisyen ve bilim insanlarını desteklemek, yurt dışındaki Türk ve yabancı akademisyen ve bilim insanlarını bilgilerinden istifa ederek Türkiye'ye yarar sağlamak, yenilikçi akademik ve bilimsel proje girişimlerini desteklemek" gibi amaç ve hedefler sıralanan TABiP'in daha "kurumsal" bir yapıya dönüşmesi büyük önem arz etmektedir.

Araştırmada yapılan analiz çerçevesinde iki kuruluşun yaptığı faaliyetlerde kamuoyu farkındalığına ve toplumsal katılıma oldukça önem verdiği görülmektedir. Günümüzde, yeni kuşağın toplumsal konulara ve sorunlara oldukça duyarlı olması ve bu sorunların çözümüne dâhil olmak istemesi, diplomasiyi sadece devletlerarasında gerçekleşen bir kavram olmaktan çıkarıp, kamusal katılımın yoğun olduğu bir sosyal/siyasi sürece dönüştürmüştür. Dolayısıyla bu iki köklü kurum faaliyetleriyle bilimin, sadece devlet ya da bilim için değil, bilimin aynı zamanda halk için yapılması gerektiğini gösteren faaliyetler sürdürdüğü izlenmiştir.

Bu çalışmada Türkiye'nin bilim diplomasisi politikası doğrultusunda T.C. Cumhurbaşkanlığı'na doğrudan bağlı, hükümet destekli ancak çalışmalarıyla kamu/özel/STK gibi birçok kurumla iş birliği içinde "Türkiye Bilim Diplomasi Kurumu (TBDK)"nun kurulması önerilmekte ve bu kuruma yönelik bir "paydaş" ve "faaliyet modeli" önerisi sunulmaktadır. Bu modelde araştırma kapsamında incelenen kurumların faaliyetleri örnek alınarak, bilim diplomasisi faaliyetlerine etkin toplum katılımını sağlayacak ulusal/uluslararası birlikler, üniversiteler, STK'lar, özel kuruluşlar ve yerel yönetimler gibi tüm paydaşlarla ortak faaliyetler düzenleyecek bir yapı tasarlanmıştır (Şekil 1). 


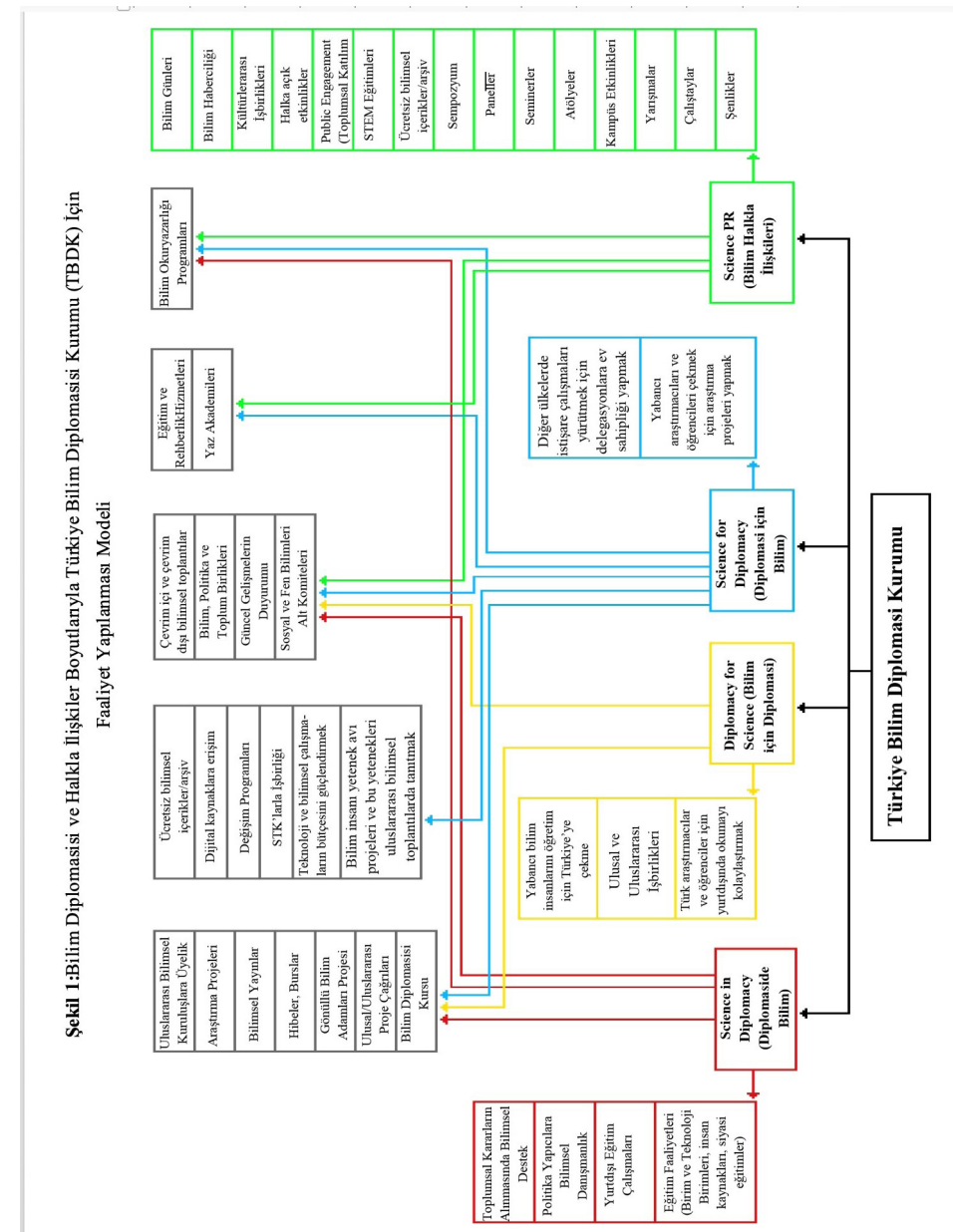

Şekil 1 ve Şekil 2'de model önerilerinde sunulduğu üzere TBDK merkezli Dışişleri Bakanlığı ve bilim/teknoloji alanında çalışan diğer bakanlıklar, kurum ve kuruluşlar arasında iş birliği ve ortak çalışma alanları oluşturulması, iletişim/ bilgilendirme ağının kurulması, bilimi ülkenin iç ve dış çıkarlarının korunmasında önemli bir aktör haline getirebilir. TBDK kapsamında üyelik, bağış alma, fon oluşturma, topluluk oluşturma, halka açık etkinlikler, açık dersler, topluma açık arşiv, yaz okulu, çevrimiçi konferanslar, sınıf etkinlikleri, sergiler, workshoplar gibi bir dizi halkla ilişkiler faaliyeti yapılabilir. Bunun için bilim diplomasisinin üç boyutu kapsamında ana konular, hedefler, projeler belirlenebilir, her bir başlık için de ayrı departmanlar, yürütme kurulları ve iletişim birimleri kurulabilir. 


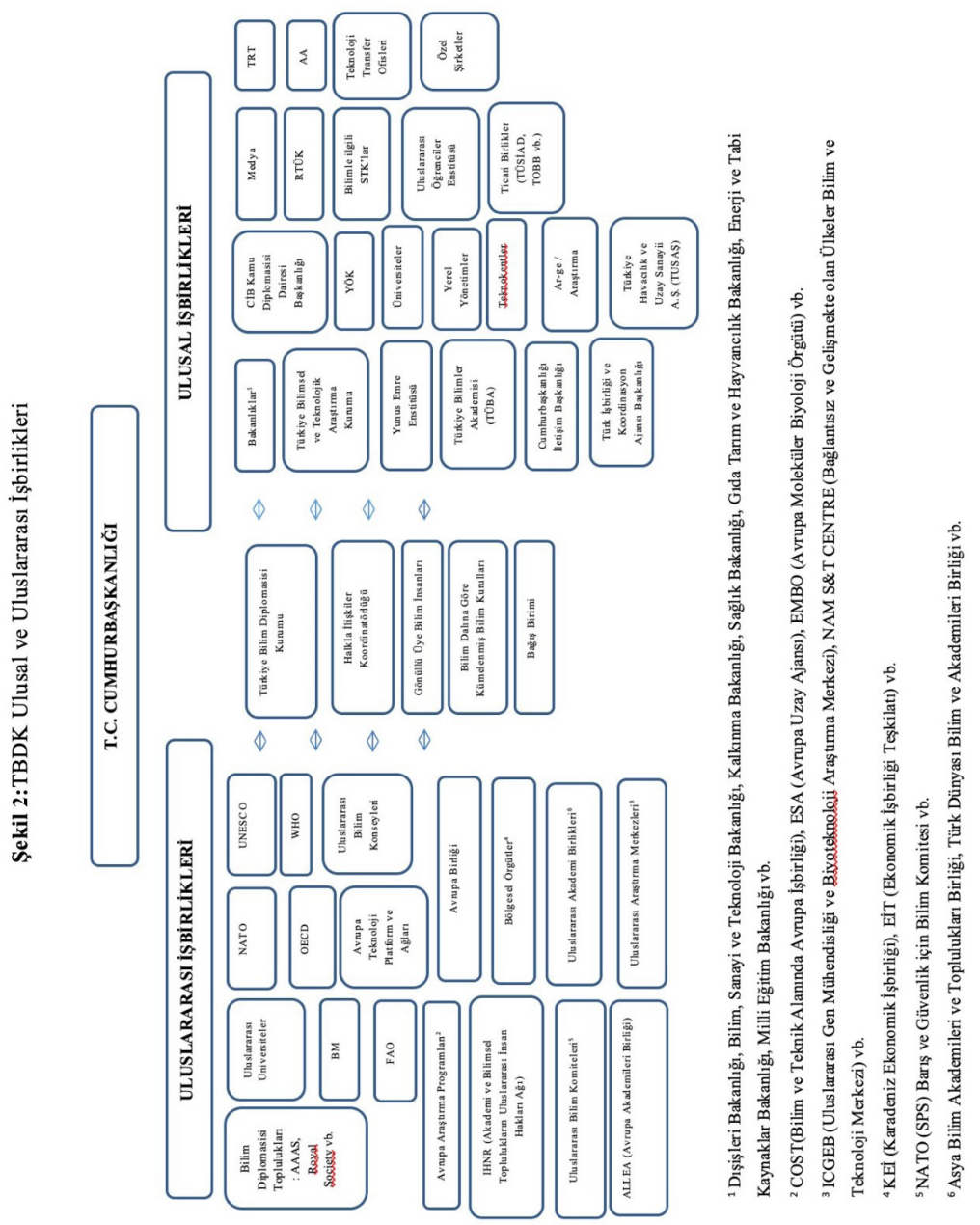

Türkiye Bilim Diplomasisi için hazırlanan ulusal ve uluslararası iş birlikleri şeması (Şekil 2) doğrultusunda kurulacak iş birlikleri yurtiçi/dışı bilimsel projelerin, anlaşmaların oluşumu ve yürütülmesinde Türk bilimi için büyük avantajlar sunma potansiyeline sahiptir. Bu avantajları iyi değerlendiren kurum da Türkiye'nin bilimsel anlamda gelişimine, tanınırlığına, itibarına ivme kazandıracaktır.

\section{Sonuç}

Bilim diplomasisi sadece dünyada evrensel sorunların çözümü için değil, dış politika hedeflerini bilimsel çalışmalarla desteklemek, uluslararası iş birlikleri kolaylaştırmak ve ülkeler arasındaki ilişkileri geliştirmek için bilim iş birliğini kullanmak amacıyla da büyük önem taşımaktadır. Öte yandan bilim diplomasisi 
çerçevesinde, bilimsel çalışmaların ulusal ve uluslararası paylaşımı sivil/toplumsal katılımı da gerektirmektedir. Buradan yola çıkarak dünyada bilim diplomasisi konusunda önemli çalışmalar yürüten Royal Society ve AAAS'nin faaliyetleri incelendiğinde, bu kuruluşların tüm çalışmalarının temelinde genel olarak faaliyetlerini kamuoyuna aktarma misyonunun olduğu görülmektedir.

Bilim diplomasisinin uluslararası ilişkilerde etkin bir biçimde kullanılması için ülkelerin bilime gerçek anlamda maddi/manevi destek ayırmaları ve bilim diplomasisi konusunda resmi ve/veya sivil "yönetim mekanizmaları" oluşturmaları gerekmektedir. Çünkü dünyanın sorunları entegre bilgi ve kurumlarla ancak çözüme erişilebilir boyutlara varmıştır. 2020 Yılında küresel boyutlu Covid-19 Pandemi süreci bilimsel diplomasinin en iyi örneklerinin yaşandığı bir dönem olmuştur. Sağlık diplomasisi de bilim diplomasisinin bir alt çalışma alanı olarak değerlendirildiğinde bu süreçte konuyla ilgili çok sayıda ortaklık ve iş birliği gerçekleştirilmiştir. Örneğin Endonezya ve Çin, yeni tip koronavirüs aşısı için iş birliği anlaşması imzalamıştır. Dünya Sağlık Örgütü, çalışmalar yapmak amacıyla farkı ülke temsilcilerinin yer aldığı bir komisyon kurmuştur. Afrika Birliği, aşı denemeleri için konsorsiyum oluşturmuştur. Dünya Sağlık Örgütü ve 30 ülke aşı, ilaç, test ve diğer sağlık teknolojileri konularında iş birliği yapmaya karar vermiştir. BM Teknoloji Bankası, BM Kalkınma Programı, BM Ticaret ve Kalkınma Konferansı ve Dünya Sağlık Örgütü ile birlikte Teknolojiye Erişim Ortaklığı'nı başlatmıştır.

Türkiye'de de özellikle üniversitelerimizin öncülüğünde örneğin COViD-19 ile ilgili birçok bilimsel çalışma yapılmaktadır. Bu gelişmeler birçok mecrada haber olarak yer almaktadır. Ancak bu gelişmelerin dünyaya duyurulması ve gerekli iş birliklerinin sağlanması için bir kurum şemsiyesi (TBDK) altında toplanması ve sistemli olarak bilim halkla ilişkiler çalışmaları yürütülmesi önemlidir. Türkiye'nin küresel ölçekte bilimsel çalışmalarda etkin bir rol oynayabilmesi için bilim diplomasisi faaliyetlerine önem vermesi gerekmektedir. Bilim süreklilik gerektiren ve destekle ilerleyen bir yapıya sahiptir. Bilgilerin birikimi ile ortaya çıkan birtakım buluşlar ve keşifler için bir bilim arşivinin ve arkasında yıllanmış kurumların olması elzemdir. Bu sebeple akademik ve bilimsel iş birlikleri kurarak bilim diplomasisi faaliyetleri yürütmek ve bu alanda kamusal katıımı sağlamak amacıyla kurumsal bir yapılanma kurulmalıdır.

Bu çalışma misyonu ve vizyonu bilim diplomasisi amaçları çerçevesinde şekillenecek bir bilim diplomasisi kurumu için bilim diplomasisinin üç boyutu ve bilim halkla ilişkileri kapsamında oluşturulacak bir paydaş ve faaliyet modeli önerisi sunmayı amaçlamıştır. Bu sayede uzun vadede hem bilimin topluma mal edilmesi ve toplumun bilime katılımı, hem de sını ötesi konuları ele almak için yine bilimi kullanarak uluslararası kalıcı ağlar kurulup, sürdürülebilir iş birlikleri oluşturulabilir. Türkiye Dünya'da bu sayede bilim diplomasisi konusunda toplumla etkileşim halinde olan önemli uluslararası bir aktör haline gelebilir. 


\section{Kaynakça}

Borcheld, R.E. (2008). Handbook of Public Communication of Science and Technology. Bucchi, M; Trench, B.,(Ed.) Public Relations in Science, Managing the Trust Portfolio içinde Routledge: Taylor\&Francis e-library.

Bose, S.; Roy. S.K.; Alwi S.F.S.; Nguyen B. (2020). Measuring customer based place brand equity (CBPBE) from a publicdiplomacy perspective: Evidence from West Bengal. Journal of Business Research. 116, 734-744.

Burakgazi, S.G. (2017). Kritik Olaylar, Politik Dökümanlar, Raporlar ve Araştırmalar Işığında Türkiye'de Bilim İletişimi. Selçuk İletişim Dergisi. 10 (1), 232-261.

Colglazier, E.W. (2018). Science Diplomacy and Future Worlds. Science \& Diplomacy, September.

Cowan, G. and Arsenault, A. (2008). Moving From Monologue to Dialogue to Collaboration: The Three Layers of Public Diplomacy. The Annals of American Academy of Political and Social Science. 616 (10), 10-30.

Duke, S. (2002). Wired Science: Use of World Wide Web and e-mail in Science Public Relations. Public Relations Review, 28, 311-324.

Entradas, M. ve Bauer M.M. (2016). Mobilisation for Public Engagement: Benchmarking the Practices of Research Institutes, Public Understanding of Science, Vol. 26, Issue 7, pp. 771-788.

Fedoroff, N.V. 2009. Science Diplomacy In The 21st Century. Cell 136 (1): 9-11.

Forman, J. (2015). Chemistry and Diplomacy: Science Education and Science Communication in Disarmament, Fall, ACS CHED CCCE Newsletter. https:// confchem.ccce.divched.org/sites/confchem.ccce.divched.org/files/2015FallCCCENLP4.pdf

Gluckman, P. D., Turekian, V. C., Grimes, R. W. and Kishi, T. (2017). N 6 (4).

Grimes R., Chamberlain Y. ve Oku A. (2014). The UK Response to Fukushima and Anglo-Japanese Relations, Science \& Diplomacy, June.

Hocking, B. (2005). Rethinking the 'New' Public Diplomacy (içinde) The New Public Diplomacy (Ed. Jan Melissen) New York, Palgrave Macmıllan.

Hutton, J. G. (1999). The Definition, Dimensions, and Domain of Public Relations. Public Relations Review, 25(2), 199-214.

İslamoğlu, H. (2009). Sosyal Bilimlerde Araştırma Yöntemleri. İstanbul: Beta Yayınları.

Jasanoff, S. (2003). Technologies of Humility: Citizen Participation in Governing Science, Minerva 41(3), 223-244.

Kaltofen, C. ve Acuto, M. (2018). Science Diplomacy: Introduction to a Boundary Problem. Global Policy, 9 (3), November, 8-14. 
Kanagarajan, S. and Sony, R. (2020). Science Communication at the Intersection of Science and International Relations: Success Stories and Learnings from the COVID-19 Pandemic. Journal of Scientific Temper. Vol 8(3\&4), July-Dec pp. 119134.

Kelley, J. R. (2009). Between Take-offs and Crash Landings: Situational Aspects of Public Diplomacy. Routledge Handbook of Public Diplomacy. Newyork: Taylor\&Francis, 72-85.

Krige, J ve Barth, K.H. (2006). Science, Technology, and International Affairs. History of Science Society 21 (1), 1-21.

Leach, J. (2015). The Role of Science Communication in International Diplomacy. Science Diplomacy, New Day or False Down?, Ed. Davis, L.S. ve Patman R.G., World Scientific Publishing Co. Pte. Ltd., 155-169.

Lederbogen, U. ve Trebbe, J. (2003). Promoting Science on the Web. Science Communication, Vol. 24, No. 3, March 2003, 333-352.

Legrand, T. ve Stone, D. (2018). Science Diplomacy And Transnational Governance Impact. Br Polit, 13, 392-408.

Majumdar, M.G. (2018). The Art of Science Diplomacy. SPE Communications, March, 1-4.

Melissen J. (2005). The New Public Diplomacy: Between Theory and Practice, Melissen, J. (Ed.) The New Public Diplomacy (içinde). New York: Palgrave Macmillan.

Mitcham, C. (Ed) (2005). Encyclopedia of Science, Technology, and Ethics. Farmington Hill: Thomson Gale.

Moomaw, W.R. (2018). Scientist Diplomats or Diplomat Scientists: Who Makes Science Diplomacy Effective? Global Policy, 9 (3), November.

Neresini, F. ve Bucchi, M. (2011). Which Indicators fort he New Public Engagement Activities? An Exploratory Study of European Research Institutions, Public Understanding of Science, 20 (1), pp. 64-79.

Nye, J.S. (2005). Yumuşak Güç. Ankara: Elips Kitap.

Peltekoğlu, F. B. (2009). Halkla Illişkiler Nedir? İstanbul: Beta Basım.

Rosenau, J. N. and Singh, J. P. (2002). Information Technologies and Global Politics: The Changing Scope of Power and Governance. SUNY Press.

Rowe, D. and Brass, K. (2011). We Take Academic Freedom Quite Seriously: How University Media Offices Menage Academic Public Communication. International Journal of Media and Cultural Politics, 7 (1): 3-20.

Schafer, M.S. (2009). From Public Understanding to Public Engagement: An Empirical Assessment of Changes in Science Coverage. Science Communication, 30(4): 475-505. 
Sharp, P. (2005). Revolutionary States, Outlaw Regimes and the Techniques of Public Diplomacy. Melissen. J. (Ed.). The New Public Diplomacy (içinde). New York: Palgrave Macmıllan.

Signitzer, B. H. and Wamser, C. (2009). Public Diplomacy: A Specific Governmental Public Relations Function. Botan, C ve Hazelton, V. (Ed.). Public Relations Theory II (içinde) New York: Taylor \& Francis, 382-411.

Signitzer, B. H. ve Coombs, T. (1992). Public Relations and Public Diplomacy: Conceptual Covergences. Public Relations Review 18 (2), 137-147.

Smith, F. L. (2014). Advancing Science Diplomacy: Indonesia And The US Naval Medical Research Unit. Social Studies of Science 44 (6), 825-847.

Snow, N. (2014). Public Diplomacy: New Dimensions and Implications. McPhail (Ed.). Global Communication: Theory, Stakeholders, and Trends (içinde) (Fourth ed) Chichester, United Kingdom: John Wiley \& Sons, Inc., 64-79.

Stigoe, J.; Lock S.J.; Willsdon, J. (2014). Why Should We Promote Public Engagement with Science?, Public Understanding of Science, Vol. 23 (1), 4-15.

Szondi, G. (2009). Central and Eastern European Public Diplomacy: A Transinational Perspective on National Reputation Management. Routledge Handbook of Public Diplomacy, Newyork: Taylor\&Francis, 292-313.

Thompson H. E. (2018). Science Diplomacy within Sustainable Development: A SIDS Perspective. Global Policy, 9 (3), November, 45-47.

Turekian, V. (2018). The Evolution of Science Diplomacy. Global Policy, 9 (3), November, 5-7.

Turekian, V., Macindoe., S., Copeland, D., Davis, L., Patman, R. and Pozza, R. (2014). The Emergence of Science Diplomacy, L. Davis and R. Patman (Eds.), Science Diplomacy: New Day or False Dawn? (içinde). Singapore: World Scientic, pp. 10-24.

Sütçü, G. (2012). New Mode of Diplomacy in the 21st Century Science Diplomacy, Eskişehir Osmangazi Üniversitesi Sosyal Bilimler Dergisi, 13 (2), 1-14.

Weiss, C. (2005). Science, Technology and International Relations. Technology in Society, 27 (3), 295-313.

Yang, A.; Klyueva, A. and Taylor, M. (2012). Beyond a Dyadic Approach to Public Diplomacy: Understanding Relationships in Multipolar World. Public Relations Review 38(5), 652-664

Yıldıım, A. ve Şimşek, H. (2016). Sosyal Bilimlerde Nitel Araştırma Yöntemleri. Ankara: Seçkin Yayınları.

Zaharna, R (2009). Mapping Out a Spectrum of Public Diplomacy Initiatives. Information and Relational Communication Frameworks. Routledge Handbook of Public Diplomacy, Newyork:Taylor\&Francis, 86-100. 
Zaharna, R., and Uysal, N. (2015). Going For The Jugular: The Challenge From The 4thquadrant Of A Relational Public Diplomacy Model. Public Relations Review. 42(1), 378-380. https://doi.org/10.1016/j.pubrev.2015.07.006.

The Royal Society and AAAS Report (2010). New Frontiers In Science Diplomacy Navigating The Changing Balance Of Power. January, The Royal Society Science Policy Centre 6-9 Carlton House Terrace London.

https://www.aaas.org/sites/default/files/New_Frontiers.pdf. Erişim tarihi: 28.08.2020

AAAS Dialogue on Science, Ethics, and Religion, www.scienceforseminaries.org , Erişim tarihi 13.09.2020.

AAAS Kurumsal Web Sitesi, www.aaas.org , Erişim tarihi 13.09.2020.

AAAS, $\quad$ https://www.influencewatch.org/non-profit/american-association-for-the-advancement-of-science/ . Erişim tarihi: 20.11.2020.

American Association for the Advancement of Science (2020). https://www.britannica.com/topic/American-Association-for-the-Advancement-of-Science.Erişim tarihi: 20.11.2020.

Anadolu Ajansı, "YEE ile TÜBiTAK'tan 'bilim diplomasisi'nde güç birliği" (2018). https://www.aa.com.tr/tr/bilim-teknoloji/yee-ile-tubitaktan-bilim-diplomasisinde-guc-birligi/1101513, Erişim tarihi: 26.11.2020.

National Research Council (2002). Knowledge and Diplomacy: Science advice in the United Nations System, Washington, DC: The National Academies Press, http://www.nap.edu/ catalog.php?record_id=10577 . Erişim tarihi: 22.11.2020.

STEMPRA Kurumsal Web Sitesi; https://www.stempra.org/uk, Erişim tarihi 20.09.2020.

Subaru Kurumsal Web Sitesi, https://www.subaru.com/education/education-causes.html ,Erişim tarihi 20.09.2020.

TABIP Projesi Kurumsal Web Sitesi,

https://www.tabip.global/ecosystem/views/portal . Erişim tarihi 20.09.2020.

TASAM (Türk Asya Stratejik araştırmalar Merkezi) Kurumsal Web Sitesi, https:// tasam.org/, Erişim tarihi 20.09.2020.

The Royal Society Kurumsal Web Sitesi. https://www.royalsociety.org . Erişim tarihi 20.09.2020.

The Royal Society Strategic Plan 2017 - 2022, https://royalsociety.org/-/media/ about-us/governance/royal-society-strategic-plan-summary-2017-2022.pdf?la=en-GB\&hash=2BE607079802A929087AEA5E8C4E94B3 . Erişim tarihi: 20.09.2020 
The Royal Society, British science society (2020) https://www.britannica.com/ topic/Royal-Society . Erişim tarihi: 20.11.2020.

Ulusal Bilim Yazarları Derneği Kurumsal Web Sitesi. https://www.nasw.org. Erişim tarihi 20.09.2020.

Who we are? AAAS- American Association for the Advancement of Science, https://www.aaas.org/. Erişim tarihi: 20.09.2020.

Report of the Science and Society Session (2007). Commission European Public Engagement in Science, Portuguese Presidency Conference, The Future of Science and Technology in Europe, 2007. https://ec.europa.eu/research/swafs/ pdf/pub_other/public-engagement-081002_en.pdf Erişim Tarihi: 23.11.2020. 